\title{
The City Dimension of the Productivity Growth Puzzle: The Relative Role of Structural Change and Within-Sector Slowdown
}

\author{
Ron Martin*, Peter Sunley**, Ben Gardiner*, Emil Evenhuis* \\ and Peter Tyler*** \\ *Department of Geography, University of Cambridge, UK \\ **School of Geography and Environment, University of \\ Southampton, UK \\ *** Department of Land Economy, University of Cambridge, UK
}

Revised Draft: November 2017

Submitted to Journal of Economic Geography

Acknowledgments: This research for this paper was undertaken as part of a project funded by the ESRC (ES/N006135/1) into Structural Transformation, Adaptability and City Economic Evolutions, as part of its Structural Transformations Programme. We are grateful to the ESRC for its support. The full team on the project also includes David Bailey (Aston Business School, UK) and Andy Pike (Centre for Urban and Regional Development Studies, Newcastle University, UK). Their support for this paper is also gratefully acknowledged. We are also indebted to three anonymous referees for their perceptive and constructive comments on an earlier version of the paper: their reports proved very helpful in sharpening and clarifying the paper's aims, arguments and narrative. 


\begin{abstract}
Across OECD countries productivity growth has slowed, not just in recent years but over the past four decades: the so-called productivity puzzle. This paper examines the differing productivity growth paths of some 85 British cities since the beginning of the 1970s, and explores how far these paths reflect differences across cities in the pace and nature of structural change. We find that while northern cities led productivity growth over 1971-91 southern cities then led after 1991. However, at the same time, the rate of productivity growth slowed across almost all cities between these two periods. We find evidence of considerable structural convergence across cities and a general tendency for the degree of specialisation to fall. This then leads to a decomposition analysis which identifies the relative contribution of between-sector (structural change) and within-sector effects to city productivity growth. The analysis reveals that that structural change - and especially the shift from manufacturing to services - has had a negative impact on productivity growth across all cities, but that within-sector productivity developments while positive and outweighing structural change effects, have also declined over the past forty-five years, as well as varying across cities. These findings point to the need for further research on the causes of this slowdown in 'within-sector 'productivity growth and why those causes appear to differ from city to city. They also point to the need for a 'place-based' dimension to policies aimed at improving national productivity performance.
\end{abstract}

Keywords: Productivity growth slowdown Cities Structural change Withinsector effects

JEL Classifications R10 047 R11 
Productivity isn't everything, but in the long run it is almost everything (Paul Krugman, 1994).

Productivity is the challenge of our time... The gap in labour productivity between the UK's two largest city economies, London and Manchester, is larger than in any other G7 country and more than double that in both Germany and Japan. A dynamic economy needs thriving cities (HM Treasury, 2015).

The productivity puzzle is among the most pressing public policy issues today (Andy Haldane, Bank of England, 2017).

\section{Introduction}

As Paul Krugman states, while productivity is certainly not the only measure of an economy's performance, it is certainly a key attribute, since it influences the generation of the wealth necessary to support high incomes and public services. As such, it is a basic determinant of societal welfare. Of course, productivity is not the same thing as welfare: the latter also includes a wide range of 'nonmarket' activities and free services that are not costed or captured by conventional measures of output, such as GDP or GVA, and thus do not enter into calculations of productivity, even though they contribute to societal wellbeing (Coyle, 2014). Nevertheless, until some better concept of 'output' is devised, traditional measures of productivity will continue to be used to make temporal and geographical comparisons of 'economic performance'. And over the long-run, wage growth and per capita income in an economy depend on productivity growth. To that extent, a low level or a slow rate of growth of productivity is justifiably a cause for concern. And in many advanced economies, there is just such concern, for in most OECD countries labour productivity growth has been on a downward trend since the 1970s (Lindbeck, 1983; Carmody, 2013).

There has in fact been considerable debate over this slowdown in productivity growth. Some attribute the apparent decline to measurement problems, to the fact that technological advances and shifts simply do not show up in conventional measures of (both labour and total factor) productivity (the socalled 'Solow Productivity Paradox' - see Triplett, 1999; Crafts, 2002). Others dispute this argument, however, and contend that the slowdown is real (Owen, 2011; Cowen 2016; Gordon, 2016; Syverson, 2016). According to Gordon (2016), for example, innovation has stalled, and technological progress no longer produces the gains in GDP that it once did (see also Pilat et al, 2002; Dupont et al, 2011). A similar view is espoused by Cowen (2016), who argues that high-tech developments have not saved advanced economies from a 
slowdown in productivity. Yet another explanation points to the fall in business dynamism over the past two to three decades (European Central Bank, 2016), as reflected in new firm formation rates: new firms are assumed to embody more advanced technology and to be more productive than old existing firms. Still others suggest that the slowdown derives in part at least from an over-regulation of product and labour markets (e.g. Conway and Nicoletti, 2007), while others focus on misallocations and mismatching of skilled and educated labour (OECD, 2015).

One of the most contentious arguments locates the cause in the structural changes that have transformed advanced economies over recent decades, specifically the shift from manufacturing and production industries to economies based overwhelmingly on services. The contention is that many services (such as retail, hospitality, personal services, public services, and even some professional and business services) have limited potential for high productivity growth, and may even be 'stagnant' as far as productivity is concerned (Baumol, 1967; Baumol et al, 1985; Williamson, 1991; Kim, 2006). What this narrative suggests, in other words, is that the observed slowdown in productivity growth has been an inevitable consequence of the progressive shift to a 'post-industrial' service economy that has occurred over the past 40 years or so. Other authors, however, take a more guarded view, pointing out that just as some services may have limited scope for productivity advance, so too do some manufacturing activities. Further, many services function as intermediary inputs to the manufacturing sector, and may not only help to raise the productivity of the latter, but themselves may have as much scope for increasing their own productivity (Oulton, 2001). The trend for manufacturing firms to outsource certain routine service activities that were previously carried out 'in house', while at the same time often developing their own customer-orientated service activities (from finance to after-care), may well also have impacted on the measurement and allocation of productivity advance as between 'manufacturing' and 'services' in complex ways. To compound matters, it may well be that measuring output and hence productivity in certain services is not at all straightforward; for example, the 'value' of certain services may have more to do with the quality of provision (including their performativity) than in their monetary cost or value. The impact of structural change on productivity growth is thus a key but difficult issue, the more so since it is widely claimed that structural change is integral to the process of economic growth (Kuznets, 1957, 1973; Pasinetti, 1993; Laitner, 2000; Freeman and Louca, 2001; Cornwall and Cornwall, 1994; Metcalfe et al, 2006; Kruger, 2008; Roncolato and Kucera, 2014). Yet, as Kruger (2008) points out, despite the importance of structural change for growth theory, the topic of structural change and its potential relevance for productivity growth are frequently neglected topics in economic research. How far structural change has contributed to the slowdown in productivity in the major economies is 
thus an important issue and in need of much more analysis.

Such analysis is not just of national, macro-economic interest, however. In recent years, there has been a veritable explosion of interest in cities as the 'engines' of wealth creation in the national economy (Jacobs, 1984; Glaeser, 2011; Florida, 2008; Moretti, 2013). One of the many facts to have emerged from this burgeoning body of work is that cities appear to differ in their growth paths of employment and per capita incomes (see for example, Glaeser, 2005; Markusen and Shrock, 2006; Moretti, 2013; Power et al, 2010; Hobor, 2013; Dijkstra et al, 2013; Michaels et al, 2013; Cowell, 2014, Storper et al, 2015; Martin et al, 2014; Martin, 2016; Martin et al, 2016). In most of these studies, the differences (and often divergence) in growth paths between cities is attributed, in part at least, to differences in their economic structures and specialisms, and particularly the extent to which cities have suffered from deindustrialisation and the success with which they have managed to rebuild their economies around a new service and 'creative sectors' mode of growth. Less is known about how far and in what ways the slowdown of national productivity growth in the advanced economies can be related to differential patterns of productivity change across cities. Given that in such nations cities account for the bulk of the aggregate economy, a city-level analysis could clearly help throw light on the causes of productivity growth slowdown. This point is stressed by Muro and Parilla (2017), who in commenting on the United States situation argue that

While the pundits are right to debate the facts and causes of slowing productivity growth at the national level, they would do well also to explore the local dimension of the problem. After all, while many of the proposed causes of malaise-less competition in industries and fewer technological breakthroughs among others-remain national, many of them may be distinctly local.

By 'local' they refer specifically to the need to examine what has been happening across US cities.

This is precisely the focus of this paper, in which our aim is to analyse the productivity growth paths of British cities since the beginning of the 1970s, and how far and in what ways these city experiences help to throw light on the 'puzzle' of national-level productivity slowdown. Such an enquiry is in fact particularly pertinent in the British case since over recent years a major debate has resurfaced over the spatially unbalanced nature of the national economy, specifically the disparity in growth and prosperity between a buoyant south of the country and a less dynamic north (see Martin, 2015). Arguments over this 'north-south divide' in fact go back to the 1980s (see Martin, 1987) - indeed, in some respects, back as far as the 1930 s - but more recently the focus of the debate has shifted from the regional level to the city scale: the reasons for the slower growth of northern Britain, it is argued, are to be found in the cities of the north, and their failure to match the growth rates of those in the south. In 
terms of employment and output growth, most southern cities have pulled well ahead of their northern counterparts (see Martin et al, 2016). The logical question that then follows is what these disparities in employment and output growth across cities imply for labour productivity growth. ${ }^{\mathbf{1}} \mathrm{How}$ far the slowdown in national labour productivity growth is itself the outcome of different trends in productivity advance across the country's cities is thus a pertinent policy issue, especially given the UK Government's recent recognition of the need for a 'place-based' dimension to national industrial policy (HM Treasury, 2015; Department of Business, Energy and Industrial Strategy, 2017). Further, the 2016 UK referendum vote to leave the European Union - so-called 'Brexit' - makes the need to improve the productivity of the nation's cities and regions all the more urgent, given that they could well face tariffs on their exports to Europe and will need to compete in other overseas markets to export their goods and services.

\section{Labour Productivity Growth Paths of British Cities}

While much of the concern over productivity growth in the UK, and in other major economies, has been over its recent slowdown, in fact the problem is of much longer standing (see, for example, Dolman, 2009; Carmody, 2013). Figure 1 shows the post-war trend in labour productivity growth (real gross domestic product per person employed) in the UK economy, with other major OECD countries for comparison. ${ }^{2}$ The general trend across these countries, allowing for cyclical effects, has been one of a long-run slowdown in productivity growth over the post-war period, especially since the mid- or late-1960s. The UK experience has been broadly in line with this pattern. After a rising trend from the beginning of the 1950s to the mid-1960s, the trend rate of productivity then fell up to the mid-1970s, remained flat up to the early-1990s, and then fell again. In the UK, as in many other OECD countries, since the Global Financial Crisis of 2007-2008, productivity growth has been all but stagnant. How have these trends in UK productivity growth worked out across the nation's cities?

In exploring this question, an immediate major issue is the lack of any comprehensive and consistent official economic time series data on productivity for city units. As part of a larger programme of research on city

\footnotetext{
${ }^{1}$ Because of the lack of any reliable or consistent time series data on capital stock at the local or city levels in the UK, it was not possible to analyse total or multiple factor productivity. Some truly heroic assumptions would have to be made to derive such time series estimates. Thus, throughout the paper, productivity refers to labour productivity, that is output (gross value added) per employed worker. These estimates are workplace based, not residence based.

${ }^{2}$ A very similar picture emerges if labour productivity is measured by output per hour worked, as also recorded in the Conference Board Total Data Base.
} 
economic evolutions, ${ }^{3}$ we have constructed new and unique data series on employment, real gross value added (GVA), and labour productivity (real GVA per employed worker at constant 2011 prices) for some 85 cities for 82 sectors of activity, yearly from 1971 to 2014 (and on 249 sectors from 1991 to 2014). ${ }^{4}$ These data and their construction are described in Appendix A. We have defined our cities spatially on the basis of (non-overlapping) travel-to-work area (TTWA) boundaries as delineated in 2011 by the UK Office for National Statistics. There are some 228 TTWAs covering the whole of the UK. The key criterion for defining TTWAs is that generally 75 percent of an area's workforce both work and live within the

\section{Figure 1: Long Run Trends in the Annual Growth Rate of Labour Productivity in the UK and other Leading Economies, 1951-2016}

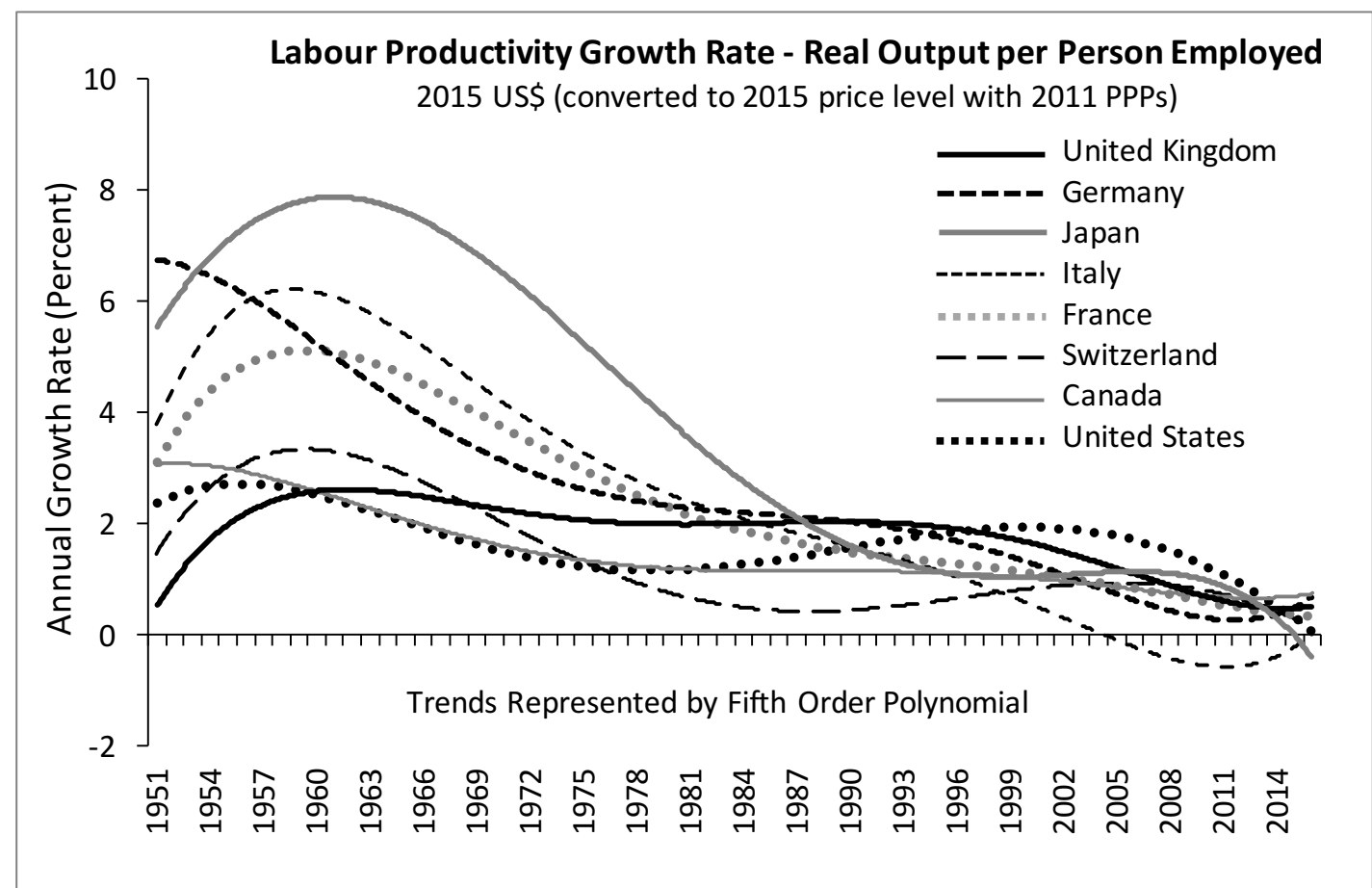

Source of data: Conference Board Total Data Base (Productivity converted to 2015 US\$, 2011 PPP). Labour productivity measured as GDP per person employed.

Note: A fifth-order polynomial in time gives a close-fit trend (with an $\mathrm{R}^{2}$ of at least 0.70 ) for a majority of the countries) and is thus shown here. In the case of the UK, a fourth order polynomial trend provides almost as good a fit, but the fifth-order trend is shown here for consistency. In her study of national productivity trends over the period 1965-2012, Carmody (2013) used a Hodrick-Prescott filter to identify trends, with very similar results, with a declining trend found in every country over the period.

same boundaries. This criterion, which in effect defines cities in terms of 'selfcontained' labour market areas, works best for those TTWAs with a sizable identifiable urban centre and a surrounding 'travel to work' hinterland, and

\footnotetext{
3 See http://www.cityevolutions.org.uk

${ }^{4}$ Since completing this paper, these data series have been updated to 2015.
} 
gives the cities so defined a reasonable degree of functional economic meaning. On this basis, we have identified some 85 cities, ranging in population size from 208,000 (Halifax) to 8.53 million (London). Together, these cities account for some 83 percent of British employment and 86 percent of British output (gross value added). ${ }^{5}$ They thus make up the bulk of the national economy.

The variation in labour productivity levels across the 85 cities in 1971 and in 2014 is shown in Figure 2. The cities have been grouped into 'northern' and 'southern' sets according to the region of their location, using the conventional way of dividing the UK into these two broad geographical areas. This gives 45 'northern' cities and 40 'southern'. Also shown is the national average (Great Britain) productivity level for the two years. What is striking is that all bar four northern cities (Aberdeen, Edinburgh, Chester and Telford) are in the bottom left-hand quadrant of the Figure, having productivity levels less than the national average both at the beginning of the period and at the end. However, at the same time, the correlation between productivity levels in 1971 and 2014, though reasonably high $(\mathrm{R}=0.686)$, is not perfect, indicating that certain shifts in relative position occurred over the period; in other words, productivity growth rates across cities have differed.

Figure 2: Labour Productivity Across 85 British Cities, 1971 and 2014 (Gross Value Added per employed worker, 2011 prices

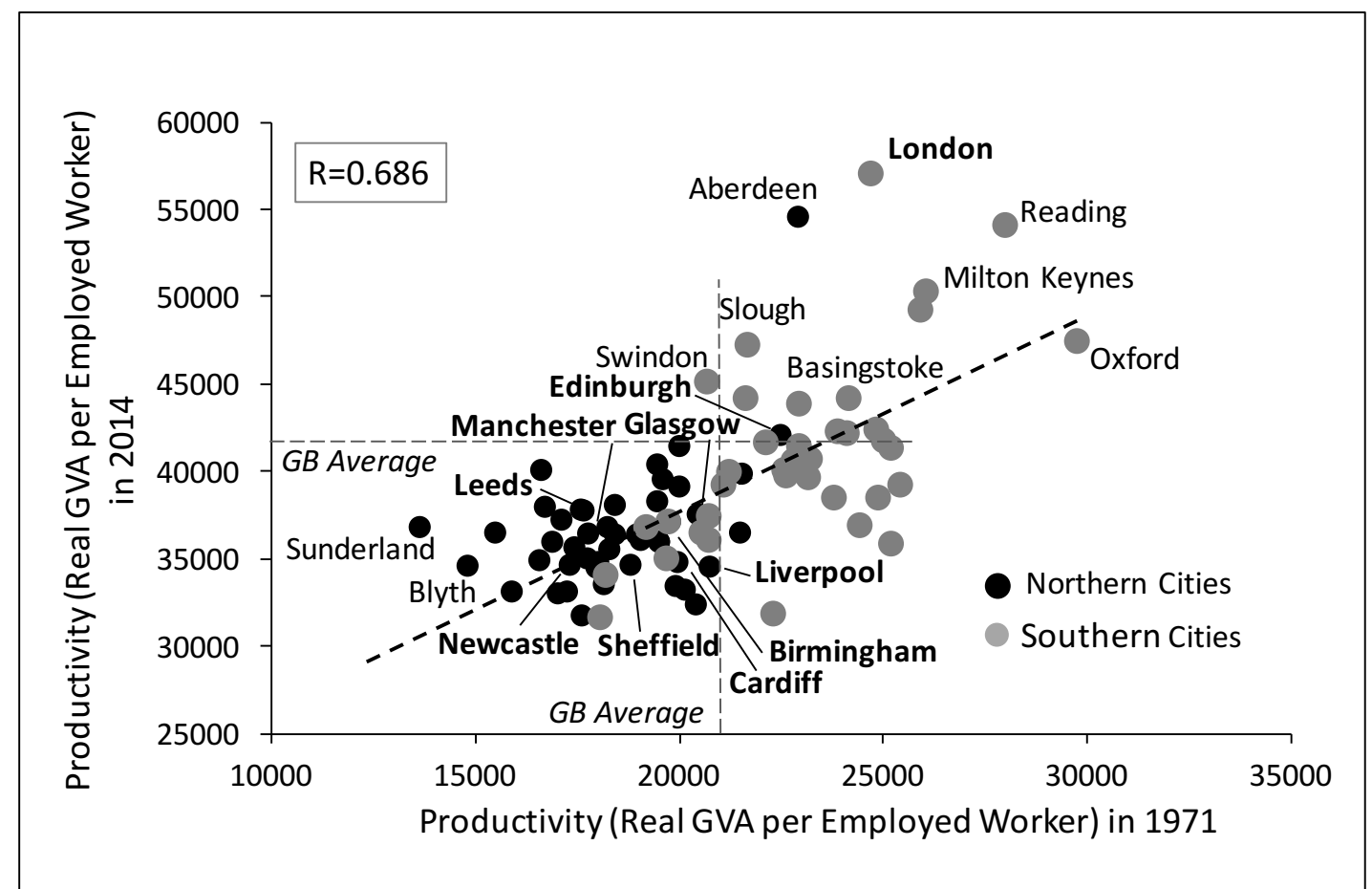

Source: Authors' data

Note: Following the 'conventional' 'North-South' division of regional Britain, 'southern' cities are defined as those in the following regions: London, South East, East of England, South West

\footnotetext{
5 Because of lack of basic data we were unable to include any cities in Northern Ireland. Correspondingly, we use Great Britain rather than the UK as the base for our comparative calculations.
} 
and East Midlands; while 'northern' cities are defined as those in the West Midlands, YorkshireHumberside, North East, North East, Scotland and Wales.

Great Britain averages shown by intersecting dashed lines. Major cities shown in bold.

Figure 3: Shifting Patterns of Labour Productivity Growth across British Cities, 1971-2014 (Gross Value added per employed worker, 2011 prices)
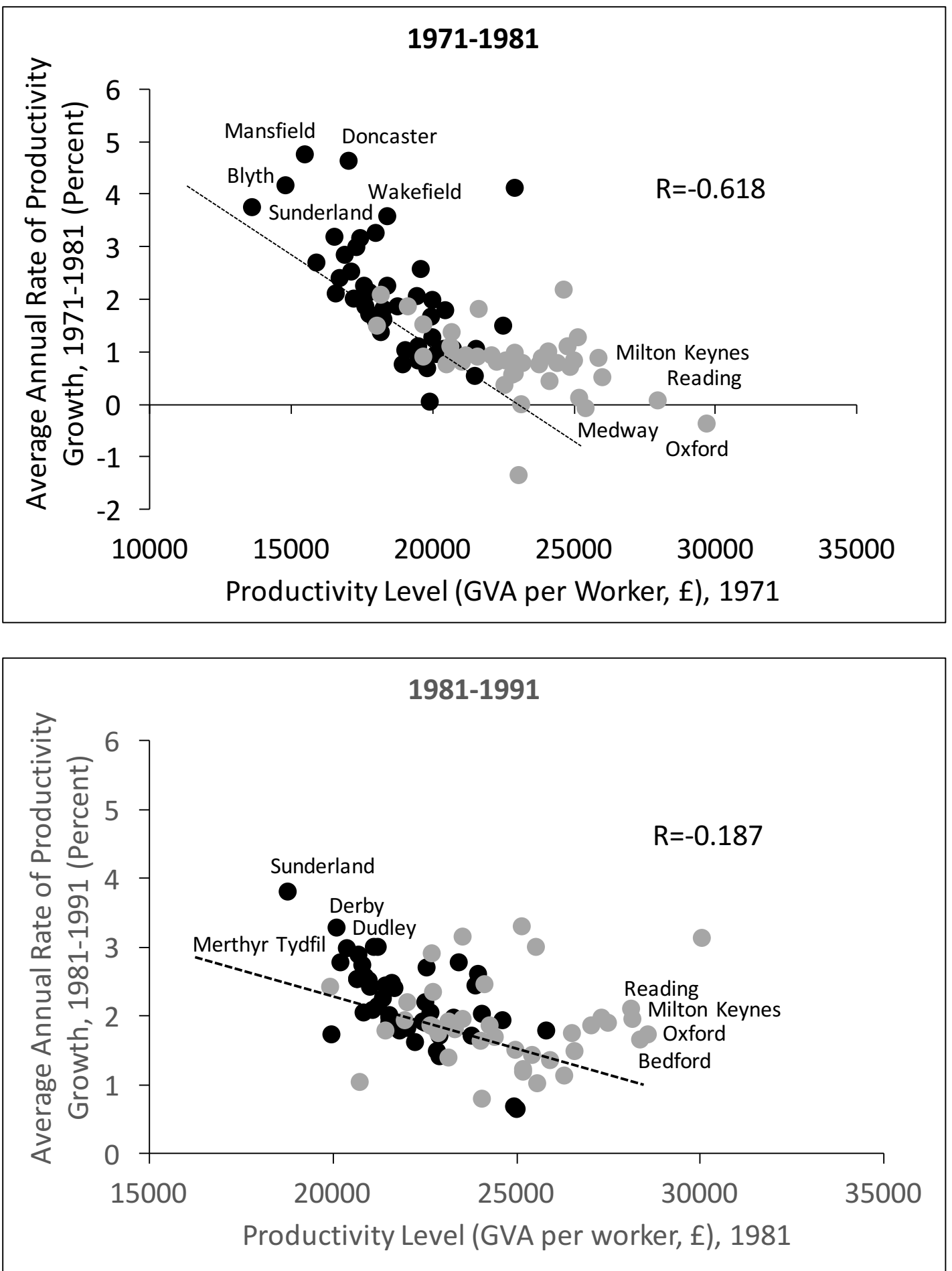

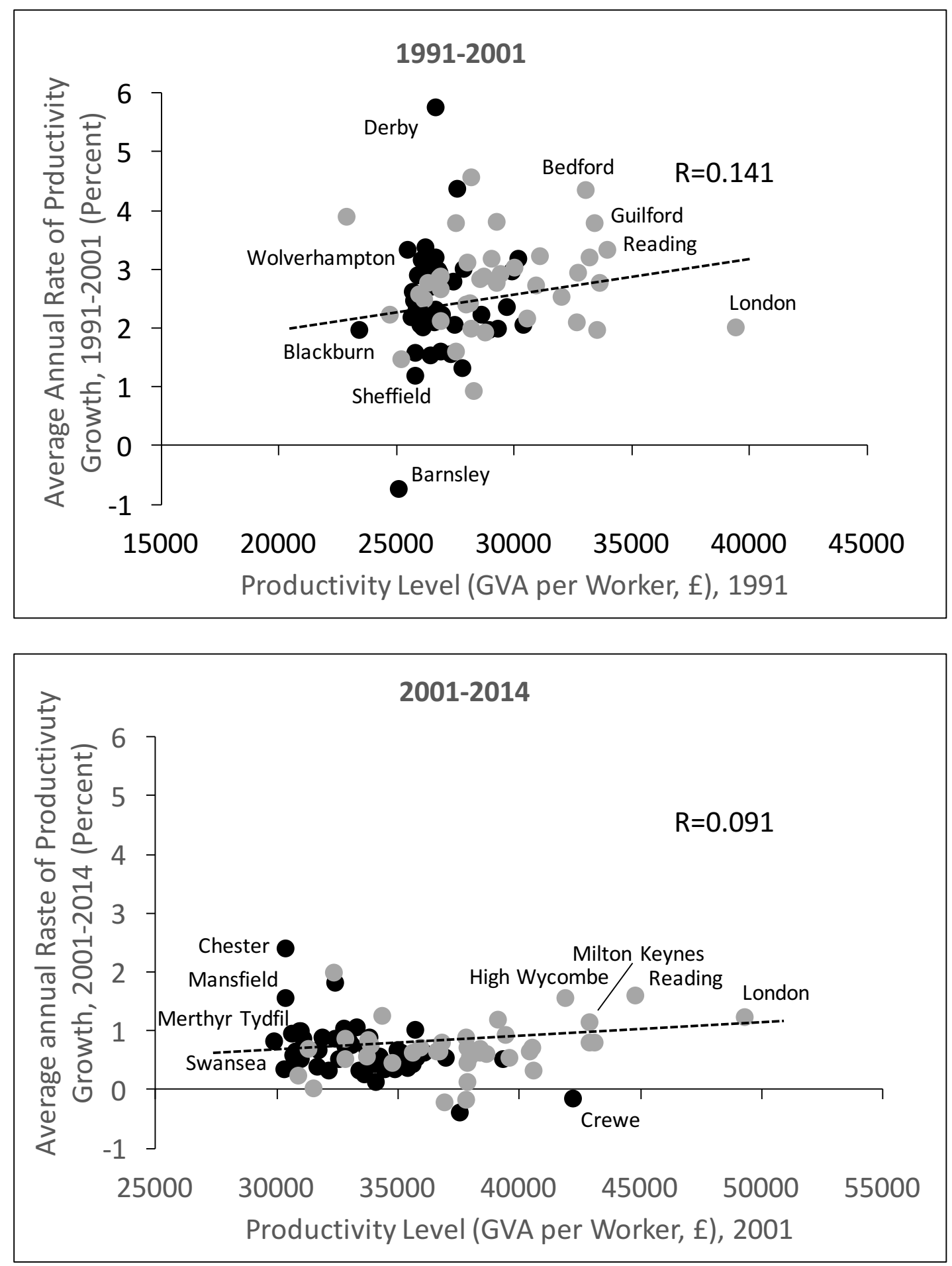

Source: Authors' data

Note: Southern cities and northern cities defined and depicted as in Figure 2. Aberdeen is excluded from these graphs on account of its very atypical structure, dominated by North Sea Oil production. 
In this context, an interesting feature emerges in the relationship across cities between their initial productivity levels and their subsequent productivity growth when the whole study period is divided into sub-periods, 1971-1981, 1981-1991, 1991-2001, and 2001-2014 (Figure 3). This reveals that over time the relationship across cities between initial productivity levels and subsequent growth has progressively changed from being negative, indicating that cities which had initially low labour productivity tended subsequently to experience faster productivity growth and 'catch up' with cities that initially had higher productivity levels, to a weakly positive relationship. Thus, while productivity levels tended to converge over the 1970s and 1980s, this tendency disappeared over the 1990s and 2000s. Further, and significantly, if we group the 85 cities into those in the 'south' of Britain, and those in the 'north', there is clear evidence of a 'switch' in relative labour productivity growth between these two geographical groups between 1971-1991 and 19912014, with northern cities as a group outpacing southern cities in the first period, but the latter out-performing the former in the more recent period (Table 1). However, while the average annual growth rate of the southern cities in the second period was higher than that group managed in the first period, it was nevertheless lower than that achieved by the northern cities in that earlier period (see also Figure 4). At the same time, the growth rate of the northern group of cities slowed appreciably between the two subperiods in question. The net result is that aggregate productivity growth for the economy as a whole slowed down: the slowdown of the northern cities between 19711991 and 1991-2014 has been a major contributing negative factor, for which

Table 1: Productivity Growth in Southern and Northern Cities (Average annual growth in GVA per employed person, percent per annum)

\begin{tabular}{lcc}
\hline & 1971-1991 & 1991-2014 \\
\hline Southern Cities & 1.84 & \\
$\quad$ London & 2.98 & 2.05 \\
Northern Cities & 2.28 & 1.95 \\
$\quad$ Manchester & 2.45 & 1.51 \\
Birmingham & 1.93 & 1.63 \\
Great Britain & 2.08 & 1.54 \\
& & 1.69 \\
\hline
\end{tabular}

Source: Authors' data

Note: Southern cities and northern cities defined as in Figure 2.

the improvement in performance of the southern cities in the 1991-2014 period has not been able to compensate. There are, then, two interrelated questions that arise from these city dimensions of the national 'productivity puzzle', namely: why the trend productivity growth rate of northern cities fell after 1991, and why the trend rate of productivity growth of southern cities 
after 1991, while certainly an improvement over that for 1971-1991, has not matched that of the northern cities during that earlier period.

Figure 4: Long Run Trends in the Annual Growth Rate of Labour Productivity in Southern and Northern Cities, 1971-2014

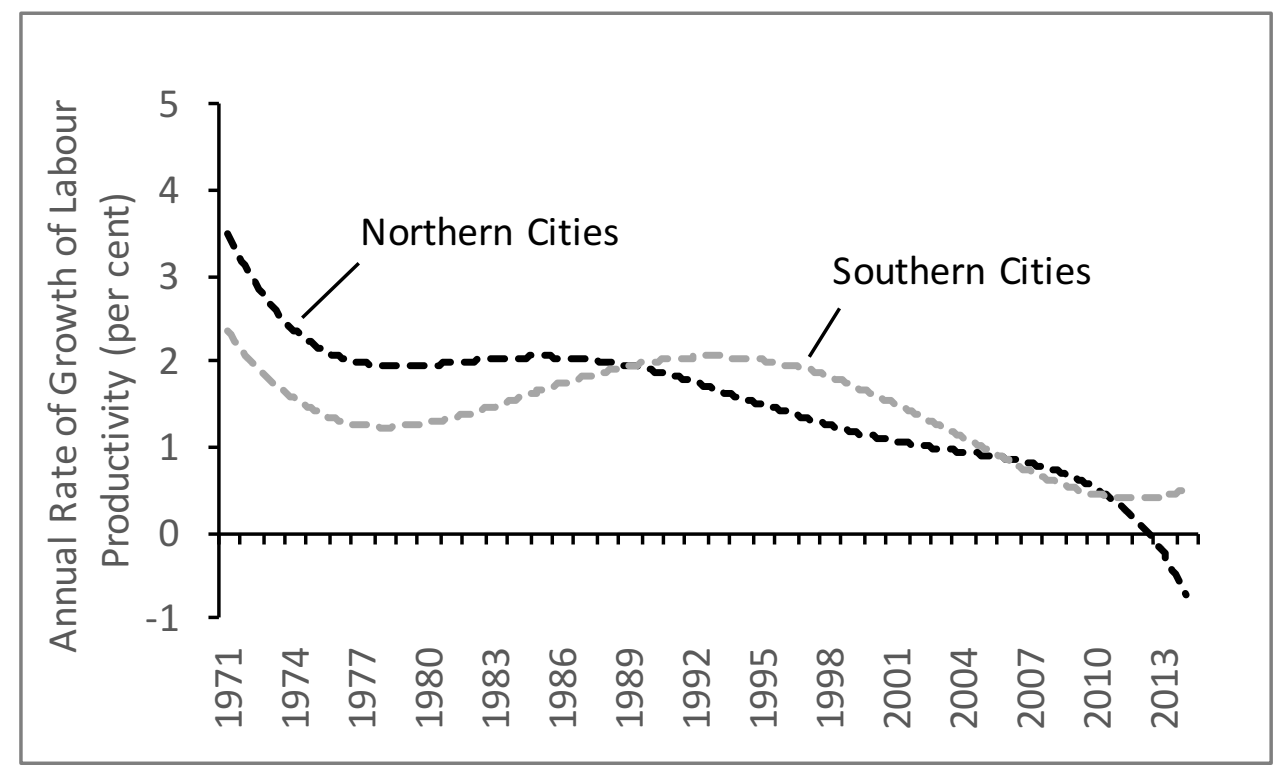

Source: Authors' data

Note: A fifth-order polynomial is used to estimate the trend for each city group. The latter are as defined for Figure 2 .

\section{Structural Change and Productivity Growth}

The fact that different cities across the UK have experienced different degrees of productivity growth slowdown immediately suggests that the causes or factors involved have themselves varied between cities, and particularly as between those in southern Britain and those in the north.

Within economic geography, much of the recent discussion of city (and regional) economic performance, including productivity, has focused on the issue of economic structure, and in particular on whether a specialised structure or a diversified one is most conducive to city (regional) growth (for a review of these two main perspectives, see for example, van der Panne, 2009). While some find that a diversified structure is more likely to promote innovation and productivity advance, in line with the notion of Jacobsian-type urban externalities, others find that specialisation is more beneficial, thus supporting the case for Marshall-Arrow-Romer type economies. Yet others have sought to move beyond the debate by positing that it is 'related variety' (or related diversity) that is the most conducive to growth and productivity advance, because it is the presence of activities that share similar or 
complementary inputs, knowledge or products, that promotes adaptability of a city's or region's economic structure and the development of new, innovative activities, which help maintain productivity growth over time (Frenken et al, 2007; Boschma, 2016). Further, still others have proposed that it is 'clustered diversity' that matters, that is the presence of several Porterian- type dynamic business clusters (Farhauer and Kröll, 2012).

Nevertheless, according to some economic geographers, it is specialisation that is the motor of city growth (Storper, 2013; Storper, et al, 2015). In their analysis of US cities, Kemeny and Storper (2015), seek to answer the question of what drives a city's economic performance by distinguishing two types of specialisation: relative specialisation in particular sectors, as measured by sector shares of a city's total employment (or output) - the conventional way of measuring city or regional specialisation - and what they call absolute specialisation, that is actual sectoral size, as measured for example by its total employment (or output). They argue that of the two measures, the clearest case is for the absolute measure. In contrast, they argue, there is less consensus around whether having a high or increasing share of an activity - an increase in (what they call) relative specialisation - would improve productivity. However, by focusing on the absolute size of sectors in cities, these authors would seem to be blurring the distinctions between concentration, agglomeration and specialisation made by Brakman, Garretsen and Marrewijk, 2009). In fact, much of Kemeny and Storper's discussion is really in terms of agglomeration, and in any case their analysis of city performance is in terms of comparative wage levels rather than comparative productivity growth.

What may matter more is not sectoral specialisation or diversity (or variety, related or unrelated) as such, but what those sectors are. Arguably a key determinant of a city's economic performance and productivity growth is the nature and success of its export or tradable base (Kaldor, 1981). The demand for a city's exports (both to the rest of the domestic economy as well as to international markets) will influence its output growth. According to Verdoorn's law (and also Frabricant's law), the rate of growth of output of a sector determines the potential for scale effects, increasing returns, new investment, and innovation in that sector (and by extension through the multiplier, in other local sectors of activity). ${ }^{6}$ These effects will influence productivity growth, which in turn (and depending on local versus external wages, and hence prices), will shape the competitiveness of the sector in export markets, and thence the demand for its output. This circular and cumulative causation process is normally assumed to operate in a positive direction

\footnotetext{
6 For a useful discussion of Verdoorn's and Fabricant's laws and how they relate to productivity growth see Scott (1989). How these laws link to processes of cumulative causation in a geographical setting is discussed in Martin (2017).
} 
(Kaldor, 1981), and was argued to apply much more to manufacturing than to services. But if the demand for a city's exports begins to decline (for example by being undermined by cheaper cost competitors elsewhere), then this circular process could be interrupted or even go into reverse, leading to a stagnation or even fall in productivity, thence a loss of competitiveness (again depending on what happens to wages and prices), and further erosion of export demand and slower output growth. Of course, the sector's firms may respond by shedding labour and/or investing in labour saving equipment in order to maintain or revive productivity advance. But if sustained, the loss of a city's tradable base could have a major dampening effect on the city's overall rate of productivity growth.

To some extent this is what has happened in manufacturing over recent decades, in the UK and most other industrialised economies. Faced by the rise of cheap labour competitors overseas, manufacturing firms in countries like the UK sought to increase productivity and hence maintain or grow demand and output by raising efficiency by shedding their less-skilled workforces. For a while at least, such rationalisation or deindustrialisation - the historic reduction in the absolute size of the manufacturing workforce - was accompanied by, and helped to maintain, productivity growth. But note that, in this instance, productivity growth was associated with a decline, not an increase in the absolute size of the manufacturing sector, an association that would seem to run counter to the Kemeny-Storper thesis. Of course, this route for securing higher productivity obviously has it limits, however, and eventually productivity growth in manufacturing becomes crucially dependent on innovation and investment.

But as some export sectors may shrink in absolute or relative employment terms, so others may expand, both absolutely and relatively. Thus, what matters also is what scope these expanding activities have for exports and productivity growth. Do these new sectors benefit from specialisation economies (of a relative or absolute kind) to the same extent and in the same way as the tradable activities that are experiencing employment decline? Specialisation economies may be specific to the activities concerned. Or the new sectors may not have the same scope for innovation, or for exports. These are precisely among the arguments that have been made about the shift to a post-industrial economy. The key point is that, as Rowthorn (2010, p. 373) stresses, the "long-run prosperity of a region is determined by the strength of its export base", where the latter includes not just manufacturing but also tradable services of various kinds, particularly knowledge based professional and business services (so-called KIBS). This argument applies no less to cities. ${ }^{7}$

7 In his study, Rowthorn shows how the tradable sectors of the northern regions of Britain have lost substantial employment, compared to southern regions, over the past forty years. He 
Changes over time in sectoral structure may therefore have either positive or negative consequences for a city's long-run productivity growth. Such changes reflect not just the different rates of employment (or output) growth (or decline) of different sectors, but also structural shifts and recompositions associated with the branching and recombination of sectors to produce new activities with associated productivity characteristics. We have already mentioned the most obvious 'between-sector' structural change associated with the long-run decline in importance, in employment terms for example, of manufacturing, and the ongoing growth in importance of services.

\section{The Changing Economic Structure of British Cities}

The scale of this structural change from an economy based on production industries (manufacturing, construction and utilities) to one dominated by private market services, followed by public services (central and local government), has been dramatic. The decline in UK production ${ }^{8}$ employment from its peak of 11.2 million (or 41.1 percent of total jobs) in 1966 to 5.7 million (18.6 percent) in 2014 represents one of the most rapid rates of deindustrialisation in the western world. Likewise, having increased over the two decades after the Second War, the share of production industries in total output steadily increased to reach a peak of 38.6 percent in 1969, and thereafter progressively declined, falling to 19.2 percent by 2014 . At the same time employment in private market services increased from 8.8 million (34.1 percent) in 1969 to 15.1 million (50.8 percent). If we add in local and central government, the service economy increased its share of total employment from 53.3 percent in 1969 to 79.1 percent in 2014, and its share of total national Gross Value Added from 38.4 percent to 80.1 percent over the same period. The macro-structure of the national economy today looks very different indeed from that of forty or so years ago.

Both northern and southern cities have been transformed by these changes (Figure 5). But some significant differences are also evident between the two groups. In 1971, the share of total employment accounted for by manufacturing in northern cities, as a group, was substantially higher than in southern cities (34.7 percent and 24.9 percent, respectively). Since then, the

does not, however, examine productivity growth as between these two broad divisions of the country. As we have just argued, it is possible, at least for a while, for a region, or city, to sustain or even improve productivity growth precisely by shedding labour.

8 Manufacturing plus construction, mining, electricity, gas and water. 
share of manufacturing has fallen relentlessly in both groups, but faster in northern cities, so that by 2014 the absolute difference between the two groups of cities had been much reduced (9.4 percent and 5.6 percent, respectively). At the same time, while the share of public (government) services in total employment was initially higher in southern cities, and has grown in both groups over the period, by 1991 northern cities had 'caught up'

Figure 5: Structural Change in Southern and Northern British Cities: Employment Shares by Broad Sector, 1971-2014

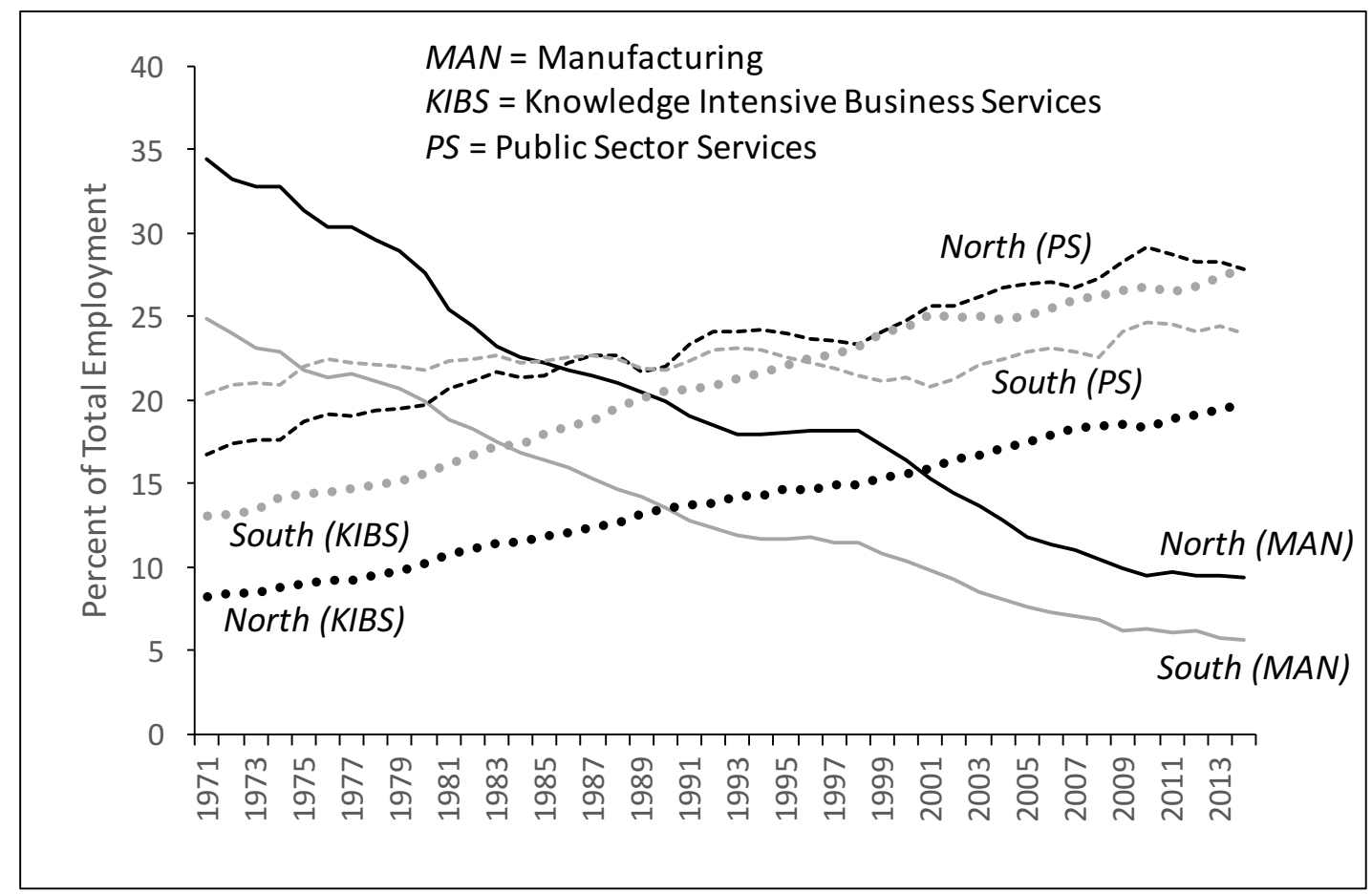

Source: Authors' own data

Note: Southern cities and northern cities defined as in Figure 2. Employment share are of the Great Britain total.

with their southern counterparts, and thereafter have moved ahead. As for knowledge-intensive business services (KIBS), their share of total employment has risen steadily in both northern and southern cities, with the share in the former consistently below that in the latter, and failing over time to match the growth of that sector in southern cities. Interestingly, in the southern city group, taken as a whole, KIBS overtook manufacturing in employment share terms in the early-1980s, whereas it was not until nearly two decades later that this occurred in the northern city group.

To explore these structural trends in more city and sectoral detail, we used the coefficient of relative specialization (see Isard, 1960; Dixon and Thirlwall, 
1975). ${ }^{9}$ This has been deployed by Krugman on a number of occasions to examine city and regional specialization (Krugman, 1991; 1993), and for that reason is often called the 'Krugman Index'. It takes the form

$$
C R S_{j t}=\sum_{i=1}^{N}\left|S_{i j t}-s_{i t}^{*}\right|
$$

where, $s_{i j}$ is the share of total employment (or output) in city $j$ accounted for by sector $i$ at time $t, s_{i}^{*}$ is the corresponding employment (or output) share of that sector in the comparator 'reference economy' also at time $t$, and $N$ is the number of sectors involved in the analysis. As defined, the index takes the value of zero when a city (or region) has exactly the same structure as the reference economy (since each absolute sectoral share difference in (1) would itself be zero), and a maximum of 2 in the case where the city shared no sector in common with the reference economy. ${ }^{\mathbf{1 0}}$ According to Krugman, the index is a "rough way of quantifying differences in structures, and hence regional specialization" (1993, p. 250). Strictly speaking, however, it tells us more about structural dissimilarity between regions, or cities, than about regional or city specialization per se, since even if the index for a city is close to zero, suggesting little difference from the reference economy, the reference economy itself could be narrowly specialized in particular sectors, so in this case both the city and the nation would be equally and similarly specialized.

Thus an additional measure is required in order to capture whether a city is specialised or diversified economically. The obvious approach to measuring the degree of diversity of a city's economic structure is to compare actual sectoral (employment or output) shares against an equi-proportion distribution of shares, that is a state of complete diversity or balanced structure. The Hirschman-Herfindahl index is probably the most commonly used measure for this sort of analysis. This is defined as the sum of the squared sectoral shares,

\footnotetext{
${ }^{9}$ There are several measures that can be used to summarise and compare city (and regional) economic structures and their evolution over time. For surveys of different measures, see, for example, Isard et al (1960); Bahl, et al (1971); Dixon and Thirwall (1975); Gibbs and Postan (1975); Kruger (2006); Palan (2010). These include the index of regional specialisation (Dixon and Thirlwall, 1975, Krugman; 1993), Shannon's Entropy Index (for example, Aiginger and Davies, 2004; Aiginger and Pfaffermayr, 2004), the Index of Inequality in Production Structure (see Cuadrado-Roura et al., 1999; Haaland et al., 1999; Landesmann, 2000; Percoco et al., 2005), the Theil Index (Brülhart and Traeger, 2005; Ezcurra and Pascual, 2007), and the Hirschman-Herfindahl Index (for example, Sapir, 1996; Davis, 1998; Storper et al, 2002; Aiginger and Pfaffermayr, 2004; Beine and Coulombe, 2007).

10 If the national economy is taken as the reference norm, then the maximum is $2[(\mathrm{~N}-1)] / \mathrm{N}$, since by definition the national economy must share at least one sector in common with at least one of its cities (regions).
} 


$$
H H I_{j t}=\sum_{i=1}^{N} s_{i j t}^{2}
$$

where, as in Equation (1), the shares $S_{i j t}$ are expressed as proportions of a city's (or region's) total employment (or output). The index ranges from a minimum of $1 / N$, when all sectoral shares are equal (maximum diversity) to an upper bound of 1 , in which case a city would be mono-specialised, that is all of its activity is in just one industry. Because the sectoral shares are squared, the index gives more weight to large sectors. ${ }^{11}$

Both the CRS (Krugman) Index and the Hirschman-Herfindahl Index can be used for identifying and tracking structural change in individual cities and regions by comparing values of the indices at different points in time. ${ }^{12}$ In the case of the CRS, by using the national economy as the reference economy, the index can illuminate whether, how far, and how fast, city economic structures are converging (declining values of the index), or diverging (increasing values of the index). ${ }^{13}$ With respect to the $H H I$, if there is proportional growth across sectors, and hence no structural change, the index would remain constant over time (Metcalfe et al, 2006). Changes in the index thus indicate structural change: successive values that moved towards $1 / N$ over time would indicate increasing equality (diversity) in economic structure, whereas a trend towards 1.0 would indicate increasing specialisation.

Table 3 shows the calculated CRS (Krugman) indices of structural specialisation (dissimilarity) by employment across 82 sectors for selected cities (most and least initially specialised, and including London and other major cities) for 1971, 1991 and 2014 (the results for all 85 cities are in Table B1 in Appendix B. The corresponding full results using output shares are given in Table B.2). For each city, the 'reference economy' in Equation (1) was defined as Great Britain minus the city in question, so as to avoid double counting (which would not be insignificant in the case of London, and to a lesser extent with Birmingham, Manchester, Sheffield, Liverpool, Glasgow and

\footnotetext{
${ }^{11}$ For this reason, the square root of the index is sometimes used (for example, Chisholm and Oeppen, 1973). We use the standard version in what follows.

12 There are measures that are intended to capture the scale and speed of structural change in a region or city economy directly, for example the Lilien Index (Lilien, 1982; Ansari et al, 2013), but these do not of themselves tell us much about whether that change is leading to diversification or specialisation of a region's or city's structure. Other studies have sought to measure excess industrial churn' and its relationship to city growth (Duranton, 2007; Findeisen and Südekum, 2008).

13 Note that the $C R S$ can be also used to chart the changing economic structure of a city relative to its own 'starting' structure, at say $t=0$, by setting the reference 'norm' $s_{i j t}^{*}$ in (1) to $s_{i j 0}$. In this instance, structural change would be indicated by rising values of the index over time, as the city increasingly diverged from its original mix of sectors.
} 
Edinburgh). Several key features stand out. First, in 1971 cities differed markedly in the degree of relative structural specialisation (dissimilarity). Second, the large cities (regional capitals) and London were less specialised than most other, smaller cities. Third, in the case of employment structure, all but one city (Slough) have experienced a decline in relative specialisation or structural dissimilarity since 1971. The trends in output structures (Appendix Table B1) are broadly similar, although some thirteen cities experienced a slight increase in relative specialisation, or divergence from the structure of the national economy. Fourth, especially in the case of employment shares, in general the more specialised a city was in 1971, the greater the reduction in specialisation over the ensuing period.

Table 3: Krugman Employment Structural Dissimilarity (Specialisation) Indices for Selected British Cities (82 sectors), 1971, 1991 and 2014

\begin{tabular}{llllllll}
\hline & $\mathbf{1 9 7 1}$ & $\mathbf{1 9 9 1}$ & $\mathbf{2 0 1 7}$ & & $\mathbf{1 9 7 1}$ & $\mathbf{1 9 9 1}$ & $\mathbf{2 0 1 7}$ \\
\hline Sunderland & 0.717 & 0.417 & 0.385 & Liverpool & 0.447 & 0.265 \\
Mansfield & 0.711 & 0.440 & 0.296 & Nottingham & 0.234 \\
Halifax & 0.686 & 0.430 & 0.407 & Edinburgh & 0.445 & 0.255 & 0.269 \\
Swansea & 0.679 & 0.321 & 0.352 & Luton & 0.434 & 0.316 & 0.314 \\
Merthyr Tydfil & 0.677 & 0.409 & 0.380 & Chelmsford & 0.434 & 0.298 & 0.281 \\
Oxford & 0.664 & 0.325 & 0.301 & Southend & 0.430 & 0.239 & 0.169 \\
Kettering & 0.659 & 0.419 & 0.349 & Worcester & 0.423 & 0.393 & 0.224 \\
Wolverhampton & 0.656 & 0.419 & 0.269 & London & 0.418 & 0.309 & 0.264 \\
Blackpool & 0.647 & 0.518 & 0.399 & Leeds & 0.411 & 0.387 & 0.387 \\
Blackburn & 0.634 & 0.410 & 0.348 & Newcastle & 0.408 & 0.270 & 0.227 \\
Dudley & 0.624 & 0.403 & 0.357 & Southampton & 0.369 & 0.258 & 0.252 \\
Birmingham & 0.526 & 0.382 & 0.175 & Slough & 0.368 & 0.249 & 0.184 \\
Bristol & 0.480 & 0.325 & 0.220 & Cardiff & 0.352 & 0.330 & 0.370 \\
Sheffield & 0.479 & 0.252 & 0.278 & Glasgow & 0.340 & 0.213 & 0.233 \\
& & & & & 0.328 & 0.209 & 0.224 \\
\hline
\end{tabular}

Notes: London and major northern regional capitals in bold Cities ranked in descending order of dissimilarity (specialisation) for 1971

Table 4: Herfindahl-Hirschman Employment Specialisation Indices for Selected British Cities (82 sectors), 1971, 1991 and 2014

\begin{tabular}{llllllll}
\hline & $\mathbf{1 9 7 1}$ & $\mathbf{1 9 9 1}$ & $\mathbf{2 0 1 7}$ & & $\mathbf{1 9 7 1}$ & $\mathbf{1 9 9 1}$ \\
& & & & & $\mathbf{2 0 1 7}$ \\
\hline Oxford & 0.081 & 0.052 & 0.054 & Birmingham & 0.042 & 0.037 & 0.042 \\
Sunderland & 0.077 & 0.043 & 0.045 & Liverpool & 0.041 & 0.047 & 0.048 \\
Huddersfield & 0.072 & 0.041 & 0.046 & Newcastle & 0.040 & 0.043 & 0.049 \\
Stoke-on-Trent & 0.071 & 0.050 & 0.044 & Cardiff & 0.039 & 0.040 & 0.047 \\
Halifax & 0.071 & 0.037 & 0.045 & Glasgow & 0.039 & 0.042 & 0.044 \\
Dudley & 0.067 & 0.043 & 0.045 & Shrewsbury & 0.038 & 0.040 & 0.044 \\
Trowbridge & 0.066 & 0.050 & 0.041 & Southampton & 0.038 & 0.042 & 0.045 \\
Bradford & 0.060 & 0.045 & 0.045 & Warrington & 0.038 & 0.039 & 0.039 \\
Middlesbrough & 0.060 & 0.045 & 0.050 & Leeds & 0.038 & 0.039 & 0.039 \\
Reading & 0.060 & 0.043 & 0.048 & Manchester & 0.037 & 0.040 & 0.039 \\
Exeter & 0.060 & 0.044 & 0.047 & London & 0.037 & 0.038 & 0.039 \\
Sheffield & 0.050 & 0.042 & 0.048 & Blackpool & 0.037 & 0.047 & 0.045 \\
Bristol & 0.047 & 0.040 & 0.042 & Slough & 0.035 & 0.034 & 0.037 \\
Edinburgh & 0.045 & 0.043 & 0.043 & Crawley & 0.034 & 0.034 & 0.033 \\
\hline
\end{tabular}

Notes: London and major northern regional capitals in bold Cities ranked in descending order of specialisation for 1971 
The corresponding $\mathrm{HH}$ indices for employment for selected cities for 1971, 1991 and 2014 are given in Table 4, with the full city results for employment and output in Tables B.3 and B.4 in Appendix B. These show several interesting features. In general, cities tend to be more specialized in terms of output structures than in employment structures; this was especially the case in the 1970s and 1980s. With respect to employment structures, nearly two-thirds of the cities experienced a decline in specialization over the period 1971-2014. Those cities that were more specialized initially underwent the largest declines. The HH structural indices for output shares show that almost all most cities became less specialized over the four decades. As in the case of the Krugman indices, it would appear that the decline in specialisation was most evident in the 1971-1991 subperiod, and that structural change since then has been slower.

Thus, what these analyses show, at the level of 82 sectors, is a dual tendency for sectoral structural convergence and an overall decline in (relative) specialisation across the British city system over the past forty years or so. ${ }^{\mathbf{1 4}} \mathrm{A}$ key question, then is what these structural trends have implied for the city patterns of productivity growth identified in Section 2.

\section{Structural Change and Productivity Growth Across British Cities}

To provide background for the city analysis, Table 5 summarises the relationship between structural shifts in employment and labour productivity for selected sectors for the British economy as a whole. These show that productivity growth has tended to be higher in the production and manufacturing industries - precisely those that have seen their employment shares fall - than in various services, precisely the sectors that have experienced the highest increases in employment share. This would seem to support the argument, alluded to earlier, that a contributing factor behind the national productivity slowdown may well be the structural shift of the economy from manufacturing to private and public services, since the latter would appear to have achieved lower rates of productivity growth than the former. However, at the same time, and importantly, Table 5 also indicates that productivity growth fell in most sectors between the two periods, including in

\footnotetext{
14 We have a more detailed sectoral breakdown, for some 249 industries, for each of the 85 cities for the subperiod 1991-2014. Analysis of these data also indicated structural convergence and a decline in specialisation across the cities of a comparable scale to that found for the 82-sector series for this same subperiod.
} 
Table 5: Change in Employment Share and Average Annual Productivity Growth of Major Sectors of the British Economy,

1971-1991 and 1991-2014

\begin{tabular}{|c|c|c|c|c|c|c|}
\hline & \multicolumn{3}{|c|}{$\begin{array}{l}\text { Change in Employment } \\
\text { Share (Percent point) }\end{array}$} & \multicolumn{3}{|c|}{$\begin{array}{l}\text { Average Annual Rate of } \\
\text { Change in Labour } \\
\text { Productivity }\end{array}$} \\
\hline & $\begin{array}{l}1971- \\
1991\end{array}$ & $\begin{array}{l}1991- \\
2014\end{array}$ & $\begin{array}{l}1971- \\
2014\end{array}$ & $\begin{array}{l}1971- \\
1991\end{array}$ & $\begin{array}{l}1991- \\
2014\end{array}$ & $\begin{array}{l}1971- \\
2014\end{array}$ \\
\hline Metals and Related & -2.71 & -1.24 & -3.95 & 3.75 & 2.03 & 3.65 \\
\hline Textiles and Related & -2.50 & -1.36 & -3.86 & 4.30 & 3.46 & 4.51 \\
\hline Light Manufacturing & -3.41 & -2.89 & -6.30 & 3.56 & 2.47 & 3.93 \\
\hline High Tech Manufacturing & -4.41 & -2.58 & -6.99 & 5.90 & 4.98 & 7.96 \\
\hline Utilities & -0.57 & -0.17 & -0.74 & 6.58 & 1.65 & 5.11 \\
\hline Construction & 0.67 & -1.23 & -0.56 & 0.43 & 0.84 & 0.69 \\
\hline Transport and Logistics & -1.05 & -1.20 & -2.25 & 2.32 & 2.42 & 2.98 \\
\hline Retail and Personal Services & 5.06 & 2.09 & 7.16 & 0.92 & 2.06 & 1.74 \\
\hline Knowledge Intensive Business Services & 6.19 & 6.53 & 12.72 & 2.53 & 2.34 & 3.06 \\
\hline Public services & 4.21 & 2.96 & 7.17 & 0.87 & 0.47 & 0.29 \\
\hline All Industries (Great Britain) & - & - & - & 2.08 & 1.69 & 2.25 \\
\hline
\end{tabular}

Source: Authors' own data

Note: Employment shares are of the Great Britain total. For definitions of these broad sectors, see Table A1 in Appendix A.

both high-tech manufacturing and knowledge intensive business services, often regarded as two key sources of dynamism in the contemporary economy. Retail and personal services were the main exception to this widespread slowdown. Thus, while the structural reorientation of the economy would seem likely to have contributed to the slowdown of national productivity growth, it would also seem that part of that slowdown has been due to 'withinsector' factors that have reduced the rate of productivity advance across most sectors, regardless of structural change.

To explore the relative contribution of these two main 'sources' of productivity growth across Britain's cities, we use a well-established decomposition technique that has been employed to analyse the relative contribution of 'between' and 'within' sector effects to aggregate national productivity growth of individual countries and across sets of countries (Foster, et al, 1998; Fagerberg, 2000; Pieper, 2000; Disney et al, 2003; Peneder, 2003; Kruger, 2006; Ocampo et al, 2009; Timmer and de Vries, 2009; McMillan and Rodrik, 2011; 
and Kucera and Roncolato, 2012; Roncolato and Kucera, 2014). ${ }^{15}$ Although the results of these studies vary according to time period, data frequency, whether structure is measured by employment shares or output shares, the choice of labour productivity or total factor productivity, and the particular variant of the decomposition technique used, somewhat surprisingly the balance of the findings is that the 'within-sector' effect dominates the 'between-sector' effect, ie. the effect due to structural change. In discussing these national studies, Haltiwanger (2000) has argued that structural change is much more intense within industries than between industries, even at detailed levels of sectoral disaggregation. At the same time, a number of studies have used the same sort of 'within' and 'between' firm decomposition to investigate productivity growth of a given sector (Baily et al, 1992, 2001; Foster et al, 1998; Bartlesman and Doms, 2000; Disney at el, 2003, Cantner and Kruger, 2006). In a similar way, these tend to find the 'within-firm' effect is greater than the 'between-firm' effect.

Following Kruger $(2006,2008)$, we can decompose a city's productivity growth rate over a given period $t$ to $t+k$ into three components:

$\frac{\Delta Y_{j t+k}}{Y_{j t}}=\frac{\sum_{i=1}^{n} s_{i j t} \Delta y_{i j t+k}}{Y_{j t}}+\frac{\sum_{i=1}^{n} \Delta s_{i j t+k}\left(y_{i j t}-Y_{j t}\right)}{Y_{j t}}+\frac{\sum_{i=1}^{n} \Delta s_{i j t+k} \Delta y_{i j t+k}}{Y_{j t}}$

where $Y_{j t}$ and $y_{i j t}$ refer, in our case, to total and sector-specific labour productivity levels (real GVA per employed worker) in city $j$ at time $t$. Note that $Y_{j t}=\sum_{i=1}^{n} s_{i j t} y_{i j t}$, where $s_{i j t}$ is sector i's share of city $j$ 's total employment. The $\Delta$ denotes the change in productivity and in employment shares between $t$ and $t+k$. The first term on the right-hand side of (3) is interpreted as the 'within-sector' effect, which is the share-weighted average productivity growth of the individual industries in city $j$ (the sectoral shares are held constant at their values at time $t$ ). The second term represents the contribution of shifts in sectoral structure, holding initial sectoral productivity differentials constant (as measured by differences from the city average productivity level). It is positive if sectors initially with above average productivity levels experience increasing shares between period $t$ and $t+k$ on average, and industries with below-average productivity levels experience falling shares of total city employment, on average. It will be negative if sectors with above (below)-

\footnotetext{
15 Several extensions and further disaggregations of Equation (3) have been proposed (Baily et al, 1992; Griliches and Regev, 1995; Olley and Pakes, 1995; Foster et al, 1998; Fagerberg, 2000; Disney et al, 2003). For example, Baily et al (1992) and Foster et al (1998) derive versions with additional terms that represent the contributions of entering and exiting establishments to aggregate productivity growth. These effects cannot be investigated here for the time period that is of interest
} 
average initial productivity levels experience falling (rising) shares of total city employment. The third term measures the combined effect of structural change and sectoral productivity growth rates over the period. It is positive if industries with positive rates of productivity growth tend to gain in terms of their shares (or more generally, if share change and productivity growth tend to have the same sign), and negative if sectors with positive productivity growth experience a decline in their share of city employment. The second and third terms in equation (3) together represent the role of 'structural change' or 'between-sector' shifts in city productivity growth.

The results are shown in Figure 6 and Table 6 . Figure 6 plots the within-sector and between-sector contributions to total percentage productivity change in Equation (3) against the total percentage productivity change, for each of the 85 cities, for the two subperiods 1971-1991 and 1991-2014. As is clear, in both subperiods the overwhelming contribution to total productivity change across the cities was from 'within-sector' improvements (which are positive in all bar one case). This finding is in line with most of the decomposition studies of national and international productivity growth mentioned above, and indicates that the primary determinant of city productivity growth has come from improvements in performance within individual sectors of activity rather than from shifts in city economic structure. The 'between-sector' or structuralchange contribution (the second plus third terms on the right-hand side of

Figure 6. Decomposition of City Productivity Growth, 1971-2014, into Structural-Change (Between-Sector) and Within-Sector Components

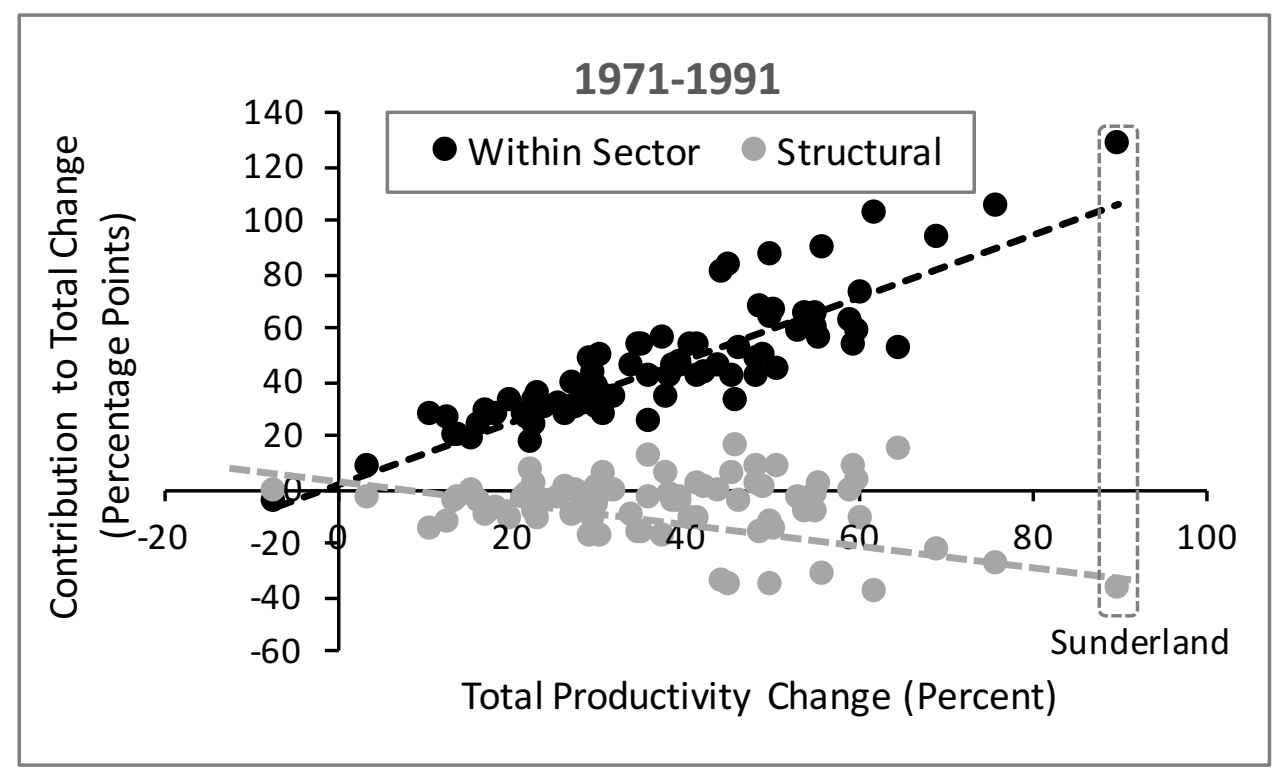




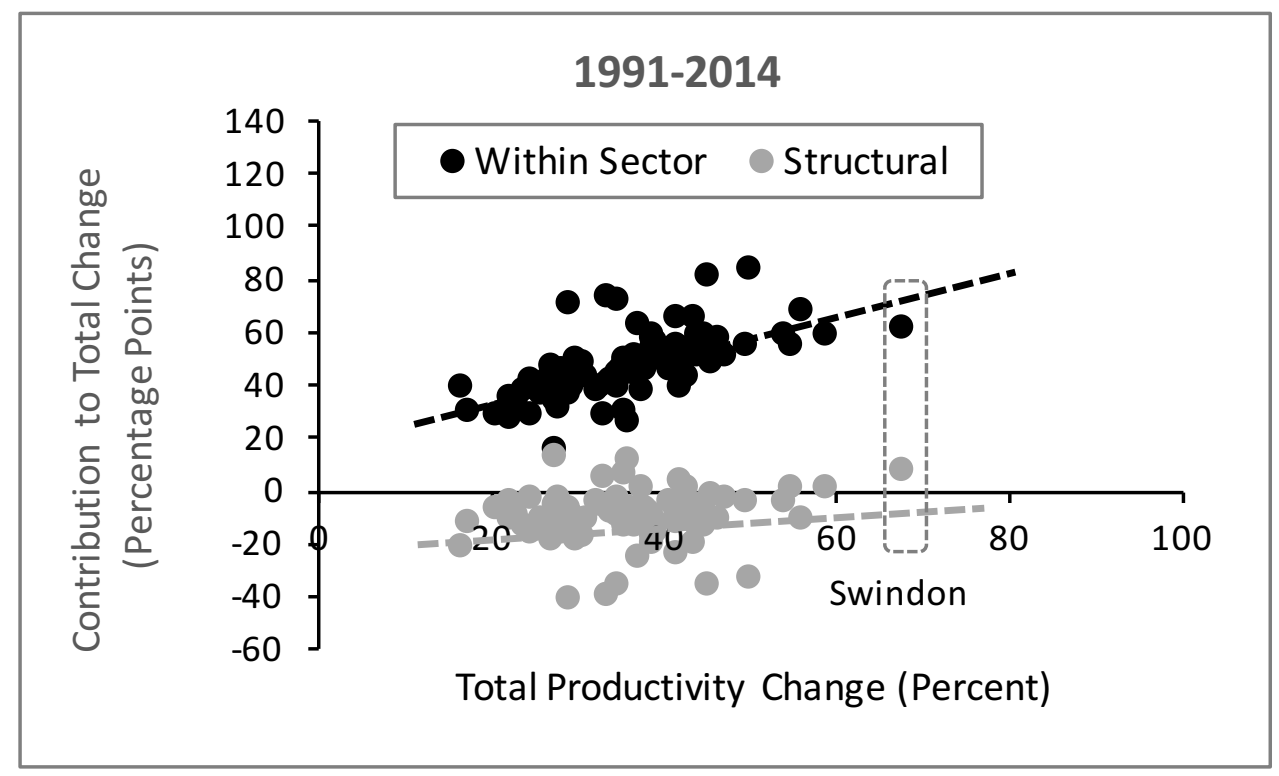

Note: The graphs should be read vertically, so that the sum of the within-sector and corresponding structural-change components for a given city equal the total productivity change for that city, given on the horizontal axis, as shown for the examples of Sunderland and Swindon.

Table 6: Decomposition of City Productivity Growth: Structural Change and Within-Sector Components, Selected Cities. Growth in Percentage points over period indicated

\begin{tabular}{|c|c|c|c|c|c|c|c|}
\hline & \multicolumn{7}{|c|}{ 1971-1991 } \\
\hline & \multicolumn{4}{|c|}{ Top Ten Cities } & \multicolumn{3}{|c|}{ Bottom Ten Cities } \\
\hline & Total & Within & Struc & tural & Total & Within & Structural \\
\hline Sunderland & 89.8 & 127.7 & -37.9 & Blackpool & 17.6 & 26.4 & -8.8 \\
\hline Blyth & 75.9 & 104.5 & -28.6 & Basingtoke & 17.1 & 28.2 & -11.1 \\
\hline Mansfied & 69.3 & 92.4 & -23.1 & Plymouth & 16.5 & 22.2 & -5.7 \\
\hline York & 64.9 & 51.2 & 13.7 & Colchester & 15.4 & 17.4 & -2.0 \\
\hline Merthyr Tydfil & 62.0 & 101.0 & -39.0 & Eastbourne & 13.8 & 18.3 & -4.5 \\
\hline Derby & 60.5 & 71.9 & -11.4 & Hull & 13.4 & 19.2 & -5.8 \\
\hline London & 59.7 & 57.2 & 2.5 & Oxford & 12.7 & 25.7 & -13.0 \\
\hline Halifax & 59.6 & 52.1 & 7.5 & Medway & 10.8 & 26.5 & -15.7 \\
\hline Middlesbrough & 59.1 & 61.2 & -2.1 & High Wycombe & 3.7 & 7.4 & -3.7 \\
\hline \multirow[t]{4}{*}{ Doncaster } & 56.1 & 89.0 & -32.9 & Leamington & -7.1 & -6.0 & -1.1 \\
\hline & \multicolumn{7}{|c|}{ 1991-2014 } \\
\hline & \multicolumn{4}{|c|}{ Top Ten Cities } & \multicolumn{3}{|c|}{ Bottom Ten Cities } \\
\hline & Total & Within & Stru & tural & Total & Within & Structural \\
\hline Swindon & 67.8 & 61.1 & 6.7 & Chelmsford & 25.9 & 38.0 & -12.1 \\
\hline Reading & 59.1 & 58.2 & 0.9 & Bedford & 25.0 & 41.3 & -16.3 \\
\hline Basingstoke & 56.4 & 67.9 & -11.5 & Cardiff & 24.8 & 27.8 & -3.0 \\
\hline Leamington & 55.2 & 54.4 & 0.8 & Doncaster & 23.8 & 37.6 & -13.8 \\
\hline Crewe & 54.2 & 58.3 & -4.1 & Colchester & 23.4 & 33.7 & -10.3 \\
\hline Eastbourne & 50.4 & 83.8 & -33.4 & Plymouth & 22.6 & 34.2 & -11.6 \\
\hline Derby & 49.9 & 54.6 & -4.7 & Hull & 22.5 & 26.9 & -4.4 \\
\hline Bradford & 47.5 & 51.0 & -3.5 & Swansea & 20.6 & 28.1 & -7.5 \\
\hline Milton Keynes & 46.5 & 57.6 & -11.1 & Preston & 17.5 & 29.7 & -12.2 \\
\hline $\begin{array}{l}\text { Tunbridge } \\
\text { Wells }\end{array}$ & 45.9 & 48.0 & -2.1 & York & 16.9 & 39.2 & -22.3 \\
\hline
\end{tabular}


Equation 3), is not only generally less important, but moreover in most cases is negative, indicating that cities have shifted structurally from higher productivity growth sectors into lower growth ones. This effect appears to have been greater in the 1971-1991 period, and reflects the falling employment shares of higher productivity growth sectors - mainly manufacturing - in cities over these years. In the 1991-2014 period, there is also some slight tendency for this negative shift to be less in those cities that recorded the highest rates of total productivity growth. Overall, however, the evidence in Figure 7 suggests that first, for almost all cities, structural change has in fact had a negative effect on productivity growth (most cities have shifted from higher productivity growth activities into lower productivity growth ones), so that this accounts for part of the slowdown in productivity growth observed in most cities, but especially northern cities; second, productivity growth in British cities has been largely due to within-sector productivity developments, but that this component of productivity growth has also slowed over the study period, compounding the negative effect of structural change. Significant firm heterogeneity in productivity, product quality, and management practice, even with narrowly defined industrial sectors, has been well documented (Melitz, 2003; Melitz and Redding, 2012). In this sense, our results confirm the findings of earlier studies that emphasise that in mature industrialised economies there are persistent and large productivity differentials within individual industries and sectors which tend to dominate productivity growth (Bartelsman and Doms, 2000; Haltiwanger, 2000; Krüger, 2006).

\section{Beyond Structure? Between-City Differences in Within- Sector Productivity Growth}

At a broad level, there are two key causes of within-sector productivity change. The first is a 'recomposition or reallocation effect' and involves the entry and exit of firms and the re-allocation of market shares between incumbent firms. In general, a higher rate of firm and plant entry leads to faster productivity growth as new entrants tend to have higher productivity than those that exit or are closed.16 If large, efficient and well-organized firms and plants gain market share this will also of course push up productivity growth. Thus, varied entrepreneurial dynamics and large firm investments in new plants across cities will strongly shape their productivity growth. The second major set of

\footnotetext{
${ }^{\mathbf{1 6}}$ Harris and Moffat (2015) argue that firm entry and closure have been the most important cause of change to total factor productivity differentials across Local Enterprise Partnership areas in the UK, but struggle to link this to the economic characteristics of these areas.
} 
(within-sector) processes centres on technological and organizational change among surviving firms which includes both the adoption of innovations as well as improved management, organizational practices and formats. Typically, these are shaped by the intensity of competition faced by firms, and by their regulatory and institutional context, and in the UK they are often proxied by the amount of capital employed per worker and linked to foreign ownership of the firm (see Webber et al, 2009). Existing industry research implies that both of these two processes are likely to be responsible for the intra-industry urban variations in productivity that we have found (Disney et al, 2003), although the relative importance of these two processes may change in different periods (see, for example, Riley and Bondibene, 2016). It is highly likely that the two sets of processes are combined in cities in mutually reinforcing ways, especially through the growth of the highest-productivity firms. In many industries, market share is dominated by a small minority of firms (Hottman et al, 2016). Not only do these leading 'frontier' firms tend to be exporters but they also have high productivity, complex organisation, and better product quality and scope, and their growth reallocates market share away from weaker, less productive competitors (Melitz and Redding, 2012; Andrews et al, 2015). Micro-evidence indicates that the distribution of firms by productivity levels is more right-skewed and stretched in some British city-regions (Oguz, 2017), which suggests that some cities are likely to have a greater prevalence of these 'frontier' and exporting firms. It is highly probable, then, that city productivity levels and trends depend considerably on the degree to which cities manage to host and encourage the emergence and growth of these efficient, exporting firms. The processes causing the emergence and growth of such firms in particular cities require much more attention. We hope to explore this issue in a future paper.

Further, greater exposure of a city's economy to global markets and competitors tends to produce a divergence in the performance of its higher and lower productivity firms (Ottaviano, 2011). In several ways, the uneven diffusion of globalisation has widened differences amongst firms within industries. In addition, ICT and digitisation are bound up with firm entry and exit, are changing firm activities, and leading to the emergence of digital activities that blur industry boundaries (including, in some instances, between what constitutes 'manufacturing' and 'services'). In this context, revisions to industry classifications are lagging well behind the growth of new activities and reorganisation of older ones. What this may imply is that the geography of 'structural change' is no longer well measured by changes in industrial classes and categories but needs to be analysed in a more fine-grained way within particular industries, for example in terms of firm capabilities, or occupational or task 'bundles'. 
There is thus a growing recognition that industry classifications may not capture those forms of activity change and restructuring that are widening differences within particular industries. Many industries now include firms that vary significantly in terms of the occupations they involve, the markets they reach, and the tasks and functions that they perform (see Baldwin, 2016). Partly, of course, this is due to the new divisions of labour emerging from supply chain re-organisation and the specialisations of areas and cities in specific tasks, stages and occupations rather than in particular sectors. In fact, some 30 years ago, Massey (1984) argued that the spatial organization of the British economy was shifting from a pattern based on urban and regional sectoral specialization - the pattern that had underpinned the industrial era of national economic growth during the 19th century and first half of the 20th - to one based on urban and regional functional specialisation, a new spatial division of labour in which shifts in technology and corporate organisation were leading to the spatial separation of the different stages and functions involved in an activity, with, say, head office functions in one location, research and development in another, and production in yet another (possibly even overseas). More recently, certain urban economists have argued that cities have been undergoing just this process, and have become less distinguished by their industrial structures than by their functional specialisms and roles (Acemoglu and Autor, 2011; Duranton and Puga, 2005). As Duranton and Puga put it:

Cities shift from specialising by sector-with integrated headquarters and plants - to specializing mainly by function - with headquarters and business services clustered in larger cities, and plants clustered in smaller cities (p. 343).

Allied closely with this process has been the trend towards the outsourcing of certain functions, and the emergence of spatially distributed production networks, often global in nature. Baldwin and Everett (2014) refer to this spatial fragmentation of production and 'slicing up of the value chain' amongst often numerous suppliers and intermediate producers, as the 'second unbundling' (the 'first unbundling' being the geographical separation of production and consumption enabled by the transport revolution of the 19th century). In effect, the vertical disintegration of many production processes (not only in manufacturing but also in some services) has been accompanied by spatial fragmentation and dispersal of the component activities that make up that process. Thus, it is perhaps not so much what sectors a city specialises in that matters for growth, but its comparative advantage to host particular stages or functions in a spatially distributedeven globally organised-production network (value chain) (Brakman et al., 
2014 ). These sorts of processes and trends towards the increasing importance of 'function' over 'sector' may be another reason for the significance of the 'within-sector' component of city productivity growth.

Unfortunately, we do not have data on the functional composition of sectors by city. In any case, the issue still remains why certain functions are likely to locate in some cities and other functions in others. Duranton and Puga, in the quote above, argue that 'higher-order', and presumably higher-value-added, functions tend to locate in larger cities, and 'lower-order' functions in smaller cities. This is in line with those authors who argue that productivity is higher in large cities, because agglomeration gives rise to various external economies or increasing returns effects (such as knowledge spillovers, inter-firm linkages, market size, and a large labour pool) which confer particular advantages to firms there. These agglomeration externalities are all assumed to increase with city size, or city density. It has been estimated, for example, that a doubling of city size increases a city's productivity level by between 4-8 percent (see Rosenthal and Strange, 2003). But not only are such estimates modest, they are based on cross-city regressions of city size and productivity levels at a particular point in time, and do not consider how long-run productivity growth is related to changes in city size, nor how agglomeration externalities themselves may change over time. ${ }^{17}$ In many ways, the notion of 'agglomeration' has become something of a conceptual chimera, a portmanteau notion that has become overworked as an explanatory device. In fact, the empirical evidence for the importance of agglomeration externalities in shaping the economic performance of cities is far from unequivocal (for a detailed survey of the field, see Beaudry and Schiffauerova, 2009).18

Further, both the nature and impact of agglomeration economies can be expected to vary over time with as a city's developmental path evolves. As a city's industries follow their own life cycles over time, so too may the scale and influence of the agglomeration effects associated with those industries: in short, agglomeration economies may also trace out evolutionary life cycles (Potter and Watts, 2011). In addition, it is by no means inevitable that the benefits to a city's firms of the various positive externalities that are believed to accrue from agglomeration increase linearly with increases in city size (or density). Various negative externalities or diseconomies - such as congestion, pollution, and high

\footnotetext{
17 It would hardly be feasible - or environmentally desirable - for a city to continue to double in size repeatedly over time as a way to raise its productivity.

18 Empirical findings vary according to how agglomeration itself is measured or proxied, what other (conditioning) variables are included in regression models testing for the impact of agglomeration, and the type and scale of geographical units used. Such is the variation in findings that it is somewhat puzzling that the claims made for agglomeration have assumed the prominence they have: it might be argued that it is often a case of theory over evidence.
} 
land and housing cost inflation - may set in as a city increases in size (or density), all of which may limit the productivity growth of the city's firms. We know relatively little empirically about such possibilities, although Baldwin et al (2002, pp. 436-441) use a theoretical NEG framework to show how "the agglomeration process, if pushed too far, can also be detrimental to growth" (p. 437) precisely because of congestion and related negative externalities. What might be as, if not more, important than city-size related agglomeration economies per se is a city's access to and connectivity to other cities, as markets and pools of (commuter) labour, that is a city's economic or market 'potential'. Cities that are close to a major centre, or that are part of a dense and well-connected regional network of other cities, may be able to benefit from market-size, supply-chain opportunities and workforce availability in ways that are denied to cities not so favourably located, connected and networked.

One important place-based influence on firm productivity singled out by recent research is the presence in a city of a high-skilled workforce. Other things being equal, a well-qualified and highly skilled workforce is assumed to confer particular advantages to the firms located there by enabling them more easily to develop new processes, products and services, in short to be more productive and hence competitive. Having a high proportion of professional, technical and highly skilled workers and occupations may therefore attract firms that carry out high-order functions in a given sector of activity. The presence of such firms in turn will attract these sections of the labour force. There is evidence, for example in the United States, that cities are becoming increasingly differentiated one from another by their relative human capital endowments, especially in terms of educational qualifications and skills (see, for example, Moretti, 2013). So cities that have traditionally attracted skilled workers, or which have succeeded in upskilling their workforce over time, might be expected to achieve a higher trend rate of productivity growth across their activities than cities which have inherited a low-skilled labour force from a previous phase of economic development, or which may have lost skills as a result of structural change and not been able to rebuild their labour forces around the new skills needed by today's growth industries.

Another key influence on a firm's productivity is its capability for innovation. There has long been a debate over whether local sectoral specialisation or diversity is the more conducive to innovation amongst a city's or region's firms. Some of the most compelling evidence suggests that a diversity of complementary activities may provide the most favourable local environment for innovation (a key contribution being Feldman and Audretsch, 1999). But much will depend on how far innovation and technical advances diffuse across 
a city's firms, and also between cities. Concern has emerged in recent years that even within a given sector, innovation and productivity advance are driven by just a few leading firms and that diffusion through the local population of firms is in fact limited, giving rise to a long tail of low innovation and lower productivity firms (World Bank, 2008; OECD, 2015; Haldane, 2017).

It is not possible to investigate the influence of these and other potential 'local' determinants of productivity growth in our 85 cities in detail because of severe data limitations. However, exploratory analysis of some plausible correlates is possible using some data series we have also constructed for British cities, in addition to the output, employment and productivity variables used above (see Table 7). Reliable data on the share of skilled employment in a city's total employment and on the number of patents per employee could not be constructed back to 1971, but only from 1981 and 1991 respectively. Apart from employment density and employment size variables, intended to capture city agglomeration-type influences, we also include a measure of each city's 'market potential', that is its distance-weighted access to the economic mass (GVA) of all other cities and also non-city travel-to-work areas. This is included to allow for the possible advantages associated with a city's spatial proximity to market opportunities and supply linkages across the national economy. Simple correlations were calculated for the whole period, 19712014, and also for the two main subperiods, 1971-91 and 1991-2014, to allow for the change in dynamics identified earlier in the paper.

The results are given in Table 8. The correlations for productivity growth over the whole period show a significant negative association with base year productivity levels, a positive association with the base year share of city employment in manufacturing and a negative association with the base year share of city employment in KIBS. Both the correlation with the base year proxy for agglomeration (employment density) and that with city size ae both positive; while the correlations of productivity growth with the share of skilled occupations in total city employment (in 1981) and with patent intensity (at 1991) are negative. Increasing shares of public employment also appear to be negatively related to city productivity growth.

Again, of particular interest are the correlations when we compare the two main subperiods, 1971-1991 and 1991-2014. The change in the correlation between city productivity growth and initial productivity level, from -0.792 to 0.011 is in line with the shifting relationship illustrated in Figure 3. Equally marked is the change in sign of the correlations of city productivity with starting year shares of manufacturing and KIBS employment: whereas in the first subperiod, cities with larger share of manufacturing employment had 
Table 7: Correlates of City Productivity Growth

Variable Description and data

PROD71 (PROD91)

MANSH71 (MANSH91)

KIBSSH71 (KIBSSH 91)

UBSH71 (PUBSH91)

KSI71 (KSI91)

AGGLOM71 (AGGLOM91)

ATEM71 (ATEM91)

PATENTS91

SKILLSSH81 (SKILLSSH91)
City productivity level in 1971 (1991) - gross value added per employed worker. Source: data constructed as described in Appendix A.

Share of Manufacturing employment as percent of city total employment in 1971(1991). Source: data constructed as described in Appendix A.

Share of Knowledge-based Business Services IBS employment as percent of city total employment in 1971 (1991). Source: data constructed as described in Appendix A. KIBS defined as SIC categories 58-66, 68-78

Share of public sector employment in 1971(1991). Source: Source: data constructed as described in Appendix A. SIC 84-86,91

Krugman Specialisation index (82 sectors). Calculated using sectoral employment shares (82 sectors), as in Equation (1). Source of data: as in Appendix A.

Total city employment 1971 (1991) per square km in relevant TTWA.

Access to economic mass (sum of GVA in all other TTWAs each inversely weighted by distance from reference city) 1971 (1991). City distances refer to straight line distances between city centres.

Number of patents per inhabitant. (1991) Patent data from, the European Patent Office (EPO) by the 8 patent sections defined by the International Patent Classification. The EPO data are based on the European Commission's NUTS3 areas, and were scaled to the 85 city TTWAs by an iterative sectoral employment allocation process, iterated across both geographical areas and patent classifications until the data reached convergence across both dimensions. Further details available are from the authors. Employment in high skilled occupations as percent of city total employment in 1981 (1991). Source: data constructed by combining sectoral employment data (see Appendix A). data for employment by occupation in each TTWA in 2014 from the Annual Population Survey, and matrices of employment by sector and occupation (SICSOC matrices) for the nations and regions of the UK, for 1981-2014, as prepared by the Warwick Institute for Employment Research (IER). High-skilled occupations are defined as those belonging to Level 4 (Managers, Directors and Senior Officials, plus Professional Occupations). Further details available are from the authors.

higher subsequent rates of productivity growth, in the second subperiod it is cities with higher initial shares of KIBS employment that have higher growth. Higher shares of public sector employment are negatively associated with city productivity growth in both subperiods. What is also noteworthy is that the positive association with both the agglomeration proxy and city population 
size falls away in the second subperiod. Equally, the correlations with the share of high skilled occupations and patenting intensity both change from negative to positive, in line with arguments that these two factors have assumed increasing importance in driving city economic performance. The shift to a positive association between productivity growth and the proportion of employment in skilled occupations is consistent with the growing importance of function as against sectoral structure. Perhaps surprisingly, access to market mass (economic potential) is insignificant in both subperiods.

Clearly, more formal modelling would help to isolate the effect of both the structural and city-specific 'within-sector' variables in Table 8, taking into account the interrelationships among the correlates themselves. We do not attempt that here, however, in part because two of the key variables in Table 8 are not measured on the same timeframe as productivity growth, and in part and crucially - because we lack the sort of firm-level data that would give us

Table 8: Correlations by Sub Periods

\begin{tabular}{lrlrllc}
\hline Correlation & PRODGR & & PRODGR & & PRODGR \\
Probability & $1971-$ & & $1971-$ & & $1991-$ \\
& 2014 & & 1991 & & 2014 \\
& & & & & \\
PROD71 & -0.648 & PROD71 & -0.792 & PROD91 & 0.011 \\
& 0.000 & & 0.000 & & 0.916 \\
MANSH7 & 0.432 & MANSH71 & 0.453 & MANSH91 & -0.029 \\
& 0.000 & & 0.000 & & 0.790 \\
KIBSSH71 & -0.315 & KIBSSH71 & -0.374 & KIBSSH91 & 0.232 \\
& 0.034 & & 0.005 & & 0.033 \\
PUBSH71 & -0.262 & PUBSH71 & -0.240 & PUBSH91 & -0.203 \\
& 0.015 & & 0.027 & & 0.063 \\
KSI71 & 0.174 & KSI71 & 0.149 & KSI91 & 0.162 \\
& 0.118 & & 0.174 & & 0.139 \\
AGGL0M71 & 0.224 & AGGLOM71 & 0.233 & AGGLOM91 & 0.077 \\
& 0.039 & & 0.032 & & 0.482 \\
SIZE71 & 0.207 & SIZE71 & 0.237 & SIZE91 & 0.054 \\
& 0.058 & & 0.029 & & 0.620 \\
ATEM71 & 0.078 & ATEM71 & 0.076 & ATEM91 & 0.069 \\
& 0.477 & & 0.491 & & 0.584 \\
PATENTS91 & -0.187 & PATENTS91 & -0.301 & PATENTS91 & 0.175 \\
& 0.087 & & 0.005 & & 0.118 \\
SKILLSSH81 & -0.253 & SKILLSSH81 & -0.452 & SKILLSSH91 & 0.263 \\
& 0.019 & & 0.000 & & 0.015 \\
& & & & & \\
\hline
\end{tabular}


more insight into 'within-sector' business dynamics and ecosystems in individual cities. Even though these results do not directly confirm the suggestion that the 'second unbundling' is an important factor regarding the change in productivity growth dynamics, the significant, positive correlations of productivity growth with the share of KIBS and share of high-skilled labour in the period for 1991 onwards, would be consistent with this thesis. Moreover, the simple correlations in Table 8 at least confirm the basic finding of the paper, namely that a major change in city productivity growth dynamics occurred around the end of 1980s-early 1990s, with the geographical locus of productivity growth shifting from northern industrial cities to southern, more service-orientated cities. This shift has contributed to the overall long-run slowdown of national productivity growth over the past forty years or so in two ways: through the shrinkage of the industrial (manufacturing) base of northern cities and through the corresponding growth of a service-based economy across all cities (but led by southern cities) in which (the scope for and pace of) productivity growth appears to be more limited.

\section{Conclusions and Implications}

There is much concern and debate surrounding the causes of the productivity slowdown or 'puzzle' that confronts the UK and other OECD economies. This paper has identified an urban dimension to add to the numerous other aspects that make up this puzzle. In Britain, the shift from manufacturing, in which productivity growth was generally high, to a service economy in much of which productivity growth appears to be lower (Table 5), has had a distinct geographical dimension. The deindustrialisation of northern cities seems to have seriously slowed down their productivity advance, while the shift to services does not seem to have offset this loss, and even in southern cities, which have led the growth of services, productivity growth has slowed (Figure 4). Admittedly, productivity within the service industries is open to measurement problems, and variations across different service activities are also large (Baily and Solow, 2001). But the negative impact on productivity growth of the shift to services across almost all of the cities studied here suggests this ongoing structural change may be far from unproblematic.

It also raises issues for the long, but still ongoing, debate about whether and to what extent sectoral specialisation drives city growth. Perhaps unlike their American counterparts, British cities have become less sectorally specialised, and have converged in terms of the sectoral structures. Given that the same time, productivity growth has slowed across Britain's cities, it might be argued that this is precisely in line with the specialisation thesis, because by becoming 
less specialised British cities have lost the localisation economies that specialisation is believed to foster.

However, the results of our decomposition analysis of city productivity growth also show that within-industry developments have in fact dominated productivity growth trends across cities, suggesting that it is now much less of a question of sectoral structure per se that determines a city's productivity growth - especially since cities have steadily converged in their sectoral structures (Section 3) - and that instead what matters, and requires in-depth investigation, is how productivity growth varies according to the intra-sectoral functions and stages of production or service provision found in cities. That is functional structure and specialisation may be more important for productivity growth than sectoral structure and specialisation. The positive association between productivity growth and the share of high-skill occupations in a city's employment base (Table 8) lends some support to this idea, since higher-order occupations tend to be associated with higher-order functions and tasks within a given sector of activity. Other research that we are conducting involving a detailed analysis of the evolution of the occupational-skill profiles of British cities since 1981, indicates a significant and persistent divide between higher skill southern cities and lower skilled northern ones. This in part reflects the different economic histories of these two city groups.

Nevertheless, the findings from our analysis have some relevant implications for policy. There is currently keen interest by the UK Government in its new industrial strategy capable (Departent of Business, Energy, Innovation and Skills, 2017) of achieving two main, interrelated objectives: improving the productivity growth rate of the national economy, and achieving a more geographically even pattern of that growth (Department of Business, Energy and Industrial Strategy, 2017). The declared recognition is that to achieve these goals a 'place-based' approach is necessary. While it is arguable whether, as it stands at the time of writing, the Government's strategy is actually sufficiently place-based, our findings in this paper certainly support the need for such a perspective. Despite the phase of 'catch-up' over the 1970s and 1980s, productivity in most northern cities remains below that of most southern cities (Figure 3). Thus, while there is a need to raise productivity growth across the whole economy - and this will require, among other things, increases in investment by firms, improvements in the skills of the workforce, a high rate of innovation by firms, and improvements in public infrastructures (physical and digital), both north and south - the task is more pressing in northern cities. Restoring the tradable base of Northern cities and upgrading their role in international supply chains in key sectors, will need explicit attention. The more so, given the UK's imminent withdrawal from the 
European Union. Depending on the eventual terms of that withdrawal, British cities may lose their preferential access to the European market and face added competitive pressures from global competitors, making a high rate of productivity growth all the more crucial. Our analysis in this paper has undoubtedly raised more questions than it has answered. But one thing it has demonstrated is that discussions around - and indeed policy actions directed at - the 'productivity puzzle' facing the UK need to take explicit account of the geographical bases and consequences of the problem.

Further, although the findings in this paper relate to the British context, they have a wider empirical and theoretical relevance. As was shown in Section 2. Several major advanced economies have also experienced a slowdown in their trend rate of productivity growth. And as Muro and Parilla (2017) argue in the case of the United States, the city dimension may well have a major bearing on understanding the dynamics and possible contributing causes of this slowdown in other advanced economies. The finding of our British analysis points to the validity of this argument. The specifics may well differ from country to country, but it could well be that the geographies of productivity growth (and slowdown) are not simply by product of national trends but constitutive of them. At the same time, our findings for British cities raise some questions for the literatures that argue for the significance of specialisation and economic structure for city economic performance. Much more research is needed, directed at changing structures and dynamics over quite long periods of time, rather than static cross section analyses at a particular point in time. One thing does seem clear, however: improving productivity is more than a 'macro-economic' issue. After all, as Jane Jacobs (1984) argued strenuously more than thirty years ago, it is in cities and cityregions where the wealth of nations is created, with nations becoming wealthy as their cities become more productive, and subsiding into low standards of living if their cities lose economic vitality.

\section{Appendix A: Construction of Basic Data Series}

The data used in this paper are those constructed and used as the basis of a wider ESRC research project (ES/N006135/1) on city economic evolutions. The resultant city time series represent the only such data set of its kind. This appendix outlines the data construction process, and the sources used. 


\section{Definition of cities}

The definition of cities used in the paper is based on the concept of the Travel To Work Area (TTWA) which is defined by the Office for National Statistics 19 as a self-contained labour market area where 'at least $75 \%$ of the area's resident workforce work in the area and at least 75\% of the people who work in the area also live in the area. The area must also have an economically active population of at least 3,500.' The TTWAs are revised every 10 years in line with new information from the census on commuting patterns, with the most recent list dating from 2011 where 228 TTWAs were identified. ${ }^{20}$ The full set of 228 TTWAs was considered too many for city-based analysis, particularly as many of them are quite small and/or do not contain urban centres of any significance. Analysis took place to determine a suitable cut-off point based on population size and density of the TTWAs in 2014, and on this basis the top 85 TTWAs ${ }^{21}$ were selected. Combined, the selected TTWAs used in the paper (and in the research project as a whole) account for $82 \%$ of Great Britain population, $83 \%$ of employment and $86 \%$ of output in 2014 .

\section{Developing a time series sectoral TTWA-city database}

While the functional definition of the TTWA is well-founded, a drawback to its use is that the data are typically only available for the year of definition, making analysis over time impossible. To circumvent this problem, we made use of Cambridge Econometrics' (CE) own Local Authority District (LAD) database which is based on 45 sectors for GVA and employment, as well as total and working-age population, over the period 1981-2014, and matched this to the 2011 TTWA boundaries. In addition, CE both extended the time period of the data back to 1971, and increased the sector definition for GVA and employment to 82 sectors. Table A.1 below provides a description and definition of the 45 and 82 sector disaggregations and their SIC codes.

\section{Table A.1: Definition of Sectors}

\begin{tabular}{|l|l|l|l|}
\hline 45 Sectors & 82 Sectors & $\begin{array}{l}\text { SIC 2007 } \\
\text { codes (82 } \\
\text { Sector) }\end{array}$ & Major sector \\
\hline $\begin{array}{l}\text { Agriculture, forestry \& } \\
\text { fishing }\end{array}$ & $\begin{array}{l}\text { Crop and animal production, } \\
\text { hunting and related service } \\
\text { activities }\end{array}$ & 1 & $\begin{array}{l}\text { Agriculture and } \\
\text { fishing }\end{array}$ \\
\hline & Forestry and logging & 2 & $\begin{array}{l}\text { Agriculture and } \\
\text { fishing }\end{array}$ \\
\hline
\end{tabular}

\footnotetext{
19 See
}

https://www.ons.gov.uk/employmentandlabourmarket/peopleinwork/employmentandemplo yeetypes/articles/traveltoworkareaanalysisingreatbritain/2016 for more information.

20 See

http://ons.maps.arcgis.com/apps/MapSeries/index.html?appid=397ccae5d5c7472e87cf0ca76 $6386 \mathrm{cc} 2$ for an interactive map of the TTWA boundaries.

$\mathbf{2 1}$ TTWAs in Northern Ireland were not considered because the CE LAD database does not cover this region, and so the process of data extension and matching was not possible. As a result, it was not possible to include any cities from this part of the UK in the analysis 


\begin{tabular}{|c|c|c|c|}
\hline 45 Sectors & 82 Sectors & $\begin{array}{l}\text { SIC } 2007 \\
\text { codes }(82 \\
\text { Sector) }\end{array}$ & Major sector \\
\hline & Fishing and aquaculture & 3 & $\begin{array}{l}\text { Agriculture and } \\
\text { fishing }\end{array}$ \\
\hline \multirow[t]{5}{*}{ Mining \& quarrying } & Mining of coal and lignite & 5 & $\begin{array}{l}\text { Coal and Other } \\
\text { mining }\end{array}$ \\
\hline & $\begin{array}{l}\text { Extraction of crude petroleum and } \\
\text { natural gas }\end{array}$ & 6 & $\begin{array}{l}\text { Oil, Gas and Mining } \\
\text { support }\end{array}$ \\
\hline & Mining of metal ores & 7 & $\begin{array}{l}\text { Coal and Other } \\
\text { mining }\end{array}$ \\
\hline & Other mining and quarrying & 8 & $\begin{array}{l}\text { Coal and Other } \\
\text { mining }\end{array}$ \\
\hline & Mining support service activities & 9 & $\begin{array}{l}\text { Oil, Gas and Mining } \\
\text { support }\end{array}$ \\
\hline \multirow[t]{3}{*}{ Food, drink \& tobacco } & Manufacture of food products & 10 & Light manufacturing \\
\hline & Manufacture of beverages & 11 & Light manufacturing \\
\hline & Manufacture of tobacco products & 12 & Light manufacturing \\
\hline \multirow[t]{3}{*}{ Textiles etc } & Manufacture of textiles & 13 & Textiles and Related \\
\hline & Manufacture of wearing apparel & 14 & Textiles and Related \\
\hline & $\begin{array}{l}\text { Manufacture of leather and related } \\
\text { products }\end{array}$ & 15 & Textiles and Related \\
\hline \multirow[t]{2}{*}{ Wood \& paper } & $\begin{array}{l}\text { Manufacture of wood and of } \\
\text { products of wood and cork, except } \\
\text { furniture; manufacture of articles } \\
\text { of straw and plaiting materials }\end{array}$ & 16 & Light manufacturing \\
\hline & $\begin{array}{l}\text { Manufacture of paper and paper } \\
\text { products }\end{array}$ & 17 & Light manufacturing \\
\hline Printing \& recording & $\begin{array}{l}\text { Printing and reproduction of } \\
\text { recorded media }\end{array}$ & 18 & Light manufacturing \\
\hline Coke \& petroleum & $\begin{array}{l}\text { Manufacture of coke and refined } \\
\text { petroleum products }\end{array}$ & 19 & Metals and Related \\
\hline Chemicals & $\begin{array}{l}\text { Manufacture of chemicals and } \\
\text { chemical products }\end{array}$ & 20 & $\begin{array}{l}\text { High tech } \\
\text { manufacturing }\end{array}$ \\
\hline Pharmaceuticals & $\begin{array}{l}\text { Manufacture of basic } \\
\text { pharmaceutical products and } \\
\text { pharmaceutical preparations }\end{array}$ & 21 & $\begin{array}{l}\text { High tech } \\
\text { manufacturing }\end{array}$ \\
\hline \multirow[t]{2}{*}{$\begin{array}{l}\text { Non-metallic mineral } \\
\text { products }\end{array}$} & $\begin{array}{l}\text { Manufacture of rubber and plastic } \\
\text { products }\end{array}$ & 22 & Light manufacturing \\
\hline & $\begin{array}{l}\text { Manufacture of other non-metallic } \\
\text { mineral products }\end{array}$ & 23 & Light manufacturing \\
\hline \multirow{2}{*}{$\begin{array}{l}\text { Metals \& metal } \\
\text { products }\end{array}$} & Manufacture of basic metals & 24 & Metals and Related \\
\hline & $\begin{array}{l}\text { Manufacture of fabricated metal } \\
\text { products, except machinery and } \\
\text { equipment }\end{array}$ & 25 & Metals and Related \\
\hline Electronics & $\begin{array}{l}\text { Manufacture of computer, } \\
\text { electronic and optical products }\end{array}$ & 26 & $\begin{array}{l}\text { High tech } \\
\text { manufacturing }\end{array}$ \\
\hline Electrical equipment & $\begin{array}{l}\text { Manufacture of electrical } \\
\text { equipment }\end{array}$ & 27 & $\begin{array}{l}\text { High tech } \\
\text { manufacturing }\end{array}$ \\
\hline Machinery & $\begin{array}{l}\text { Manufacture of machinery and } \\
\text { equipment n.e.c. }\end{array}$ & 28 & $\begin{array}{l}\text { High tech } \\
\text { manufacturing }\end{array}$ \\
\hline Motor vehicles & $\begin{array}{l}\text { Manufacture of motor vehicles, } \\
\text { trailers and semi-trailers }\end{array}$ & 29 & $\begin{array}{l}\text { High tech } \\
\text { manufacturing }\end{array}$ \\
\hline $\begin{array}{l}\text { Other transport } \\
\text { equipment }\end{array}$ & $\begin{array}{l}\text { Manufacture of other transport } \\
\text { equipment }\end{array}$ & 30 & $\begin{array}{l}\text { High tech } \\
\text { manufacturing }\end{array}$ \\
\hline
\end{tabular}




\begin{tabular}{|c|c|c|c|}
\hline 45 Sectors & 82 Sectors & $\begin{array}{l}\text { SIC } 2007 \\
\text { codes }(82 \\
\text { Sector) }\end{array}$ & Major sector \\
\hline \multirow{2}{*}{$\begin{array}{l}\text { Other manufacturing \& } \\
\text { repair }\end{array}$} & Manufacture of furniture & 31 & Light manufacturing \\
\hline & $\begin{array}{l}\text { Other manufacturing; Repair and } \\
\text { installation of machinery and } \\
\text { equipment }\end{array}$ & 32,33 & Light manufacturing \\
\hline Electricity \& gas & $\begin{array}{l}\text { Electricity, gas, steam and air } \\
\text { conditioning supply }\end{array}$ & 35 & Utilities \\
\hline \multirow[t]{4}{*}{$\begin{array}{l}\text { Water, sewerage \& } \\
\text { waste }\end{array}$} & $\begin{array}{l}\text { Water collection, treatment and } \\
\text { supply }\end{array}$ & 36 & Utilities \\
\hline & Sewerage & 37 & Utilities \\
\hline & $\begin{array}{l}\text { Waste collection, treatment and } \\
\text { disposal activities; materials } \\
\text { recovery }\end{array}$ & 38 & Utilities \\
\hline & $\begin{array}{l}\text { Remediation activities and other } \\
\text { waste management services. This } \\
\text { division includes the provision of } \\
\text { remediation services, i.e. the } \\
\text { cleanup of contaminated buildings } \\
\text { and sites, soil, surface or ground } \\
\text { water. }\end{array}$ & 39 & Utilities \\
\hline Construction & $\begin{array}{l}\text { Construction of buildings, Civil } \\
\text { engineering, Specialised } \\
\text { construction activities }\end{array}$ & $41,42,43$ & Construction \\
\hline Motor vehicles trade & $\begin{array}{l}\text { Wholesale and retail trade and } \\
\text { repair of motor vehicles and } \\
\text { motorcycles }\end{array}$ & 45 & $\begin{array}{l}\text { Transport and } \\
\text { Logistics }\end{array}$ \\
\hline Wholesale trade & $\begin{array}{l}\text { Wholesale trade, except of motor } \\
\text { vehicles and motorcycles }\end{array}$ & 46 & $\begin{array}{l}\text { Transport and } \\
\text { Logistics }\end{array}$ \\
\hline Retail trade & $\begin{array}{l}\text { Retail trade, except of motor } \\
\text { vehicles and motorcycles }\end{array}$ & 47 & $\begin{array}{l}\text { Retail and Personal } \\
\text { Services }\end{array}$ \\
\hline Land transport & $\begin{array}{l}\text { Land transport and transport via } \\
\text { pipelines }\end{array}$ & 49 & $\begin{array}{l}\text { Transport and } \\
\text { Logistics }\end{array}$ \\
\hline Water transport & Water transport & 50 & $\begin{array}{l}\text { Transport and } \\
\text { Logistics }\end{array}$ \\
\hline Air transport & Air transport & 51 & $\begin{array}{l}\text { Transport and } \\
\text { Logistics }\end{array}$ \\
\hline \multirow[t]{2}{*}{ Warehousing \& postal } & $\begin{array}{l}\text { Warehousing and support } \\
\text { activities for transportation }\end{array}$ & 52 & $\begin{array}{l}\text { Transport and } \\
\text { Logistics }\end{array}$ \\
\hline & Postal and courier activities & 53 & $\begin{array}{l}\text { Transport and } \\
\text { Logistics }\end{array}$ \\
\hline Accommodation & Accommodation & 55 & $\begin{array}{l}\text { Retail and Personal } \\
\text { Services }\end{array}$ \\
\hline $\begin{array}{l}\text { Food \& beverage } \\
\text { services }\end{array}$ & $\begin{array}{l}\text { Food and beverage service } \\
\text { activities }\end{array}$ & 56 & $\begin{array}{l}\text { Retail and Personal } \\
\text { Services }\end{array}$ \\
\hline \multirow[t]{4}{*}{ Media } & Publishing activities & 58 & $\begin{array}{l}\text { Knowledge Intensive } \\
\text { Business Services }\end{array}$ \\
\hline & $\begin{array}{l}\text { Motion picture, video and } \\
\text { television programme production, } \\
\text { sound recording and music } \\
\text { publishing activities }\end{array}$ & 59 & $\begin{array}{l}\text { Knowledge Intensive } \\
\text { Business Services }\end{array}$ \\
\hline & $\begin{array}{l}\text { Programming and broadcasting } \\
\text { activities }\end{array}$ & 60 & $\begin{array}{l}\text { Knowledge Intensive } \\
\text { Business Services }\end{array}$ \\
\hline & Telecommunications & 61 & Knowledge Intensive \\
\hline
\end{tabular}




\begin{tabular}{|c|c|c|c|}
\hline 45 Sectors & 82 Sectors & $\begin{array}{l}\text { SIC } 2007 \\
\text { codes }(82 \\
\text { Sector) }\end{array}$ & Major sector \\
\hline & & & Business Services \\
\hline \multirow[t]{2}{*}{ IT services } & $\begin{array}{l}\text { Computer programming, } \\
\text { consultancy and related activities }\end{array}$ & 62 & $\begin{array}{l}\text { Knowledge Intensive } \\
\text { Business Services }\end{array}$ \\
\hline & Information service activities & 63 & $\begin{array}{l}\text { Knowledge Intensive } \\
\text { Business Services }\end{array}$ \\
\hline \multirow[t]{3}{*}{ Financial \& insurance } & $\begin{array}{l}\text { Financial service activities, except } \\
\text { insurance and pension funding }\end{array}$ & 64 & $\begin{array}{l}\text { Knowledge Intensive } \\
\text { Business Services }\end{array}$ \\
\hline & $\begin{array}{l}\text { Insurance, reinsurance and } \\
\text { pension funding, except } \\
\text { compulsory social security }\end{array}$ & 65 & $\begin{array}{l}\text { Knowledge Intensive } \\
\text { Business Services }\end{array}$ \\
\hline & $\begin{array}{l}\text { Activities auxiliary to financial } \\
\text { services and insurance activities }\end{array}$ & 66 & $\begin{array}{l}\text { Knowledge Intensive } \\
\text { Business Services }\end{array}$ \\
\hline Real estate & Real estate activities & 68 & $\begin{array}{l}\text { Knowledge Intensive } \\
\text { Business Services }\end{array}$ \\
\hline Legal \& accounting & Legal and accounting activities & 69 & $\begin{array}{l}\text { Knowledge Intensive } \\
\text { Business Services }\end{array}$ \\
\hline $\begin{array}{l}\text { Head offices \& } \\
\text { management } \\
\text { consultancies }\end{array}$ & $\begin{array}{l}\text { Activities of head offices; } \\
\text { management consultancy activities }\end{array}$ & 70 & $\begin{array}{l}\text { Knowledge Intensive } \\
\text { Business Services }\end{array}$ \\
\hline \multirow[t]{2}{*}{$\begin{array}{l}\text { Architectural \& } \\
\text { engineering services }\end{array}$} & $\begin{array}{l}\text { Architectural and engineering } \\
\text { activities; technical testing and } \\
\text { analysis }\end{array}$ & 71 & $\begin{array}{l}\text { Knowledge Intensive } \\
\text { Business Services }\end{array}$ \\
\hline & $\begin{array}{l}\text { Scientific research and } \\
\text { development }\end{array}$ & 72 & $\begin{array}{l}\text { Knowledge Intensive } \\
\text { Business Services }\end{array}$ \\
\hline \multirow[t]{3}{*}{$\begin{array}{l}\text { Other professional } \\
\text { services }\end{array}$} & Advertising and market research & 73 & $\begin{array}{l}\text { Knowledge Intensive } \\
\text { Business Services }\end{array}$ \\
\hline & $\begin{array}{l}\text { Other professional, scientific and } \\
\text { technical activities }\end{array}$ & 74 & $\begin{array}{l}\text { Knowledge Intensive } \\
\text { Business Services }\end{array}$ \\
\hline & Veterinary activities & 75 & $\begin{array}{l}\text { Retail and Personal } \\
\text { Services }\end{array}$ \\
\hline \multirow[t]{6}{*}{$\begin{array}{l}\text { Business support } \\
\text { services }\end{array}$} & Rental and leasing activities & 77 & $\begin{array}{l}\text { Retail and Personal } \\
\text { Services }\end{array}$ \\
\hline & Employment activities & 78 & $\begin{array}{l}\text { Retail and Personal } \\
\text { Services }\end{array}$ \\
\hline & $\begin{array}{l}\text { Travel agency, tour operator and } \\
\text { other reservation service and } \\
\text { related activities }\end{array}$ & 79 & $\begin{array}{l}\text { Retail and Personal } \\
\text { Services }\end{array}$ \\
\hline & Security and investigation activities & 80 & $\begin{array}{l}\text { Knowledge Intensive } \\
\text { Business Services }\end{array}$ \\
\hline & $\begin{array}{l}\text { Services to buildings and landscape } \\
\text { activities }\end{array}$ & 81 & $\begin{array}{l}\text { Knowledge Intensive } \\
\text { Business Services }\end{array}$ \\
\hline & $\begin{array}{l}\text { Office administrative, office } \\
\text { support and other business } \\
\text { support activities }\end{array}$ & 82 & $\begin{array}{l}\text { Knowledge Intensive } \\
\text { Business Services }\end{array}$ \\
\hline $\begin{array}{l}\text { Public Administration } \\
\text { \& Defence }\end{array}$ & $\begin{array}{l}\text { Public administration and defence; } \\
\text { compulsory social security }\end{array}$ & 84 & Public Services \\
\hline Education & Education & 85 & Public Services \\
\hline Health & Human health activities & 86 & Public Services \\
\hline \multirow[t]{2}{*}{ Residential \& social } & Residential care activities & 87 & Public Services \\
\hline & $\begin{array}{l}\text { Social work activities without } \\
\text { accommodation }\end{array}$ & 88 & Public Services \\
\hline Arts & $\begin{array}{l}\text { Creative, arts and entertainment } \\
\text { activities }\end{array}$ & 90 & $\begin{array}{l}\text { Knowledge Intensive } \\
\text { Business Services }\end{array}$ \\
\hline
\end{tabular}




\begin{tabular}{|l|l|l|l|}
\hline 45 Sectors & 82 Sectors & $\begin{array}{l}\text { SIC 2007 } \\
\text { codes (82 } \\
\text { Sector) }\end{array}$ & Major sector \\
\hline Recreational services & $\begin{array}{l}\text { Libraries, archives, museums and } \\
\text { other cultural activities }\end{array}$ & 91 & $\begin{array}{l}\text { Knowledge Intensive } \\
\text { Business Services }\end{array}$ \\
\hline & Gambling and betting activities & 92 & $\begin{array}{l}\text { Retail and Personal } \\
\text { Services }\end{array}$ \\
\hline & $\begin{array}{l}\text { Sports activities and amusement } \\
\text { and recreation activities }\end{array}$ & 93 & $\begin{array}{l}\text { Retail and Personal } \\
\text { Services }\end{array}$ \\
\hline & $\begin{array}{l}\text { Activities of membership } \\
\text { organisations }\end{array}$ & 94 & $\begin{array}{l}\text { Retail and Personal } \\
\text { Services }\end{array}$ \\
\hline Other services & $\begin{array}{l}\text { Repair of computers and personal } \\
\text { and household goods }\end{array}$ & 95 & $\begin{array}{l}\text { Retail and Personal } \\
\text { Services }\end{array}$ \\
\hline & Other personal service activities & 96 & $\begin{array}{l}\text { Retail and Personal } \\
\text { Services }\end{array}$ \\
\hline
\end{tabular}

The data construction process is summarised below:

(i) Cambridge Econometrics LAD database (1981-2014, 45 sectors)

CE maintains a disaggregated database of employment ${ }^{22}$ and (constant price) GVA data by industry ( 45 detailed sectors) from 1981 for all unitary authorities and local authority districts in Great Britain. This database is formed from a UKlevel 86-sector database, which is based on raw data from the ONS and CE's own estimates. Regional (NUTS1) data are constructed at the 45-sector level, which are scaled and made consistent with the UK sectoral data. These data (back to 1992 for employees and 1996 for self-employed) are based on the quarterly workforce jobs data from the ONS as the main dataset which provides data by 19 industries by region, type (full-time, part-time and selfemployed) and gender. To move from the 19 industries to 45 sectors, data from the Business Registry and Employment Survey (BRES) and Annual Business Inquiry (ABI), based on SIC07, were used to generate industry shares by each region. The GVA data are consistent with sectoral data at NUTS 2 level from the ONS Regional Accounts.

(ii) Extending the time period back to 1971

To extrapolate the dataset back to 1971, the growth rates of CE's existing historical dataset are used, which are themselves based on older ONS data from the Census of Employment and Annual Business Inquiry (ABI). These older datasets were converted to the latest standard industrial classification (SIC07) to maintain consistency with the more recent data. Historical boundary changes for regions and local authorities were also adjusted for, as part of this process, to ensure consistency.

(iii) Increasing disaggregation to 82 sectors

22 The measure of employment is workplace based jobs, which include full-time, part-time and self-employed. 
At local area level, employment data are the most readily available from the ONS (through NOMIS ${ }^{23}$ ), and these data were the first to be collected and processed. The latest available data from the Business Register and Employment Survey (BRES ${ }^{24}$ ) based on SIC 2007 were obtained, with older vintages of data from BRES, ABI and the Census of Employment ${ }^{25}$ being used to construct consistent historical growth rates which were then applied to the latest levels to give a consistent back series for each sector and local authority district. Table A. 2 below provides a summary of sources.

Table A.2: Datasets used for detailed sector disaggregation

\begin{tabular}{|l|l|l|}
\hline Dataset & Time period & Sectors \\
\hline BRES & $2009-2014$ & 86 (effectively 82) 26 \\
\hline BRES & $2008-2009$ & 86 (effectively 82) \\
\hline $\begin{array}{l}\text { Annual Business Inquiry - Employee } \\
\text { Analysis }\end{array}$ & $1998-2008$ & 60 (split to 82) \\
\hline $\begin{array}{l}\text { Annual Business Employment -Survey } \\
\text { Employee Analysis }\end{array}$ & $1991-1998$ & 60 (split to 82) \\
\hline $\begin{array}{l}\text { Census of employment - Employee } \\
\text { Analysis }\end{array}$ & $1975-1981$ & 183 (aggregated to 82) \\
\hline $\begin{array}{l}\text { Census of employment - Employee } \\
\text { Analysis }\end{array}$ & $1971-1974$ & 183 (aggregated to 82) \\
\hline
\end{tabular}

The GVA data were then constructed by applying NUTS2-level productivity data (as provided by the ONS) to the employment data. This required the mapping of NUTS2 regions to districts and the mapping of the detailed sectors to the fewer sectors for which sub-national productivity data is available from the ONS.

Finally, LAD-level population data were collected from the ONS mid-year population estimates and presented alongside the employment and GVA data.

(iv) Fitting the LAD database to TTWA definitions

With the LAD database complete, the final process was to match the areas to the TTWA definitions. There was no easy way to do this - because both LADs and TTWAs are non-overlapping geographies all allocations were required to add up. The process was a sequential one, matching the boundaries, essentially looking at large urban agglomerations and estimating the proportions of which LAD should go in which TTWA. An error margin of $+/-5 \%$ was used to judge whether the combined proportions of LAD populations was sufficiently close to the TTWA population and density in 2011. As the focus of the work was on larger urban areas,

\footnotetext{
23 https://www.nomisweb.co.uk/

24 BRES is an ONS business survey which (from 2010 onwards) replaced the Annual Business Inquiry (ABI).

25 Also obtained from NOMIS.

26 Certain of the 86 sectors mentioned in the table did not map well to the 45 sectors. As a result, the number of sectors were aggregated to map 82 sectors to the 45 .
} 
the matching process was concentrated mostly on those areas that would subsequently be used for more detailed analysis.

\section{Appendix B: Specialisation Indices by City}

Table B1: Krugman Employment Structural Dissimilarity (Specialisation) Indices for British Cities (82 sectors), 1971, 1991 and 2014

Cities ranked in descending order of dissimilarity (specialisation) for 1971

\begin{tabular}{|c|c|c|c|c|c|c|c|}
\hline & 1971 & 1991 & 2014 & & 1971 & 1991 & 2014 \\
\hline Sunderland & 0.717 & 0.417 & 0.385 & Crewe & 0.510 & 0.314 & 0.242 \\
\hline Mansfield & 0.711 & 0.440 & 0.296 & Stevenage & 0.510 & 0.335 & 0.292 \\
\hline Halifax & 0.686 & 0.430 & 0.407 & Doncaster & 0.504 & 0.339 & 0.363 \\
\hline Swansea & 0.679 & 0.321 & 0.352 & Plymouth & 0.503 & 0.382 & 0.343 \\
\hline Merthyr Tydfil & 0.677 & 0.409 & 0.380 & Barnsley & 0.502 & 0.398 & 0.354 \\
\hline Oxford & 0.664 & 0.325 & 0.301 & Leicester & 0.501 & 0.313 & 0.280 \\
\hline Kettering-Wellingborough & 0.659 & 0.419 & 0.349 & Durham and Bishop Auckland & 0.500 & 0.417 & 0.357 \\
\hline Wolverhampton & 0.656 & 0.419 & 0.269 & Tunbridge Wells & 0.497 & 0.280 & 0.280 \\
\hline Blackpool & 0.647 & 0.518 & 0.399 & Bedford & 0.493 & 0.272 & 0.234 \\
\hline Blackburn & 0.634 & 0.410 & 0.348 & Hull & 0.483 & 0.320 & 0.316 \\
\hline Dudley & 0.621 & 0.403 & 0.357 & Bristol & 0.480 & 0.325 & 0.220 \\
\hline Middlesbrough & 0.617 & 0.444 & 0.305 & Peterborough & 0.480 & 0.335 & 0.289 \\
\hline Trowbridge & 0.612 & 0.346 & 0.246 & Sheffield & 0.479 & 0.252 & 0.278 \\
\hline Coventry & 0.609 & 0.379 & 0.296 & Warrington and Wigan & 0.468 & 0.296 & 0.278 \\
\hline Derby & 0.606 & 0.430 & 0.295 & Shrewsbury & 0.462 & 0.259 & 0.279 \\
\hline Stoke-on-Trent & 0.599 & 0.414 & 0.325 & Medway & 0.460 & 0.276 & 0.191 \\
\hline Newport & 0.597 & 0.403 & 0.325 & High Wycombe and Aylesbury & 0.459 & 0.297 & 0.265 \\
\hline Aberdeen & 0.592 & 0.524 & 0.474 & Crawley & 0.458 & 0.362 & 0.285 \\
\hline Huddersfield & 0.589 & 0.380 & 0.351 & Brighton & 0.454 & 0.300 & 0.280 \\
\hline Birkenhead & 0.584 & 0.394 & 0.289 & Preston & 0.453 & 0.295 & 0.286 \\
\hline Colchester & 0.581 & 0.354 & 0.273 & Cambridge & 0.452 & 0.311 & 0.240 \\
\hline Motherwell \&Airdrie & 0.577 & 0.362 & 0.359 & Guildford & 0.450 & 0.285 & 0.257 \\
\hline Northampton & 0.573 & 0.383 & 0.332 & Liverpool & 0.447 & 0.265 & 0.234 \\
\hline Bradford & 0.568 & 0.363 & 0.307 & Nottingham & 0.445 & 0.255 & 0.269 \\
\hline Milton Keynes & 0.551 & 0.324 & 0.315 & Swindon & 0.442 & 0.282 & 0.255 \\
\hline Falkirk and Stirling & 0.550 & 0.365 & 0.288 & Norwich & 0.440 & 0.269 & 0.222 \\
\hline Dunfermline and Kirkcaldy & 0.550 & 0.381 & 0.325 & Lincoln & 0.439 & 0.309 & 0.243 \\
\hline Basingstoke & 0.549 & 0.376 & 0.366 & Ipswich & 0.436 & 0.310 & 0.251 \\
\hline Blyth and Ashington & 0.548 & 0.398 & 0.408 & Edinburgh & 0.434 & 0.316 & 0.314 \\
\hline Exeter & 0.544 & 0.338 & 0.268 & Luton & 0.434 & 0.298 & 0.281 \\
\hline Gloucester & 0.540 & 0.313 & 0.297 & Chelmsford & 0.430 & 0.239 & 0.164 \\
\hline Bournemouth & 0.535 & 0.329 & 0.287 & Southend & 0.423 & 0.393 & 0.224 \\
\hline Chester & 0.535 & 0.322 & 0.261 & Worcester and Kidderminster & 0.418 & 0.309 & 0.264 \\
\hline Chichester & 0.530 & 0.311 & 0.264 & London & 0.411 & 0.387 & 0.387 \\
\hline Wakefield & 0.529 & 0.382 & 0.368 & Leeds & 0.408 & 0.270 & 0.227 \\
\hline Chesterfield & 0.529 & 0.446 & 0.252 & Newcastle & 0.396 & 0.258 & 0.252 \\
\hline Birmingham & 0.526 & 0.308 & 0.175 & Southampton & 0.368 & 0.249 & 0.184 \\
\hline Leamington Spa & 0.525 & 0.322 & 0.338 & Slough & 0.352 & 0.330 & 0.370 \\
\hline Telford & 0.522 & 0.450 & 0.376 & Cardiff & 0.340 & 0.213 & 0.233 \\
\hline Portsmouth & 0.519 & 0.311 & 0.266 & Glasgow & 0.328 & 0.209 & 0.224 \\
\hline Dundee & 0.518 & 0.345 & 0.304 & Manchester & 0.324 & 0.187 & 0.169 \\
\hline Reading & 0.513 & 0.378 & 0.393 & & & & \\
\hline York & 0.512 & 0.357 & 0.263 & & & & \\
\hline Eastbourne & 0.511 & 0.492 & 0.270 & & & & \\
\hline
\end{tabular}

Note: London and major regional capitals ('Core cities') in bold 
Table B2: CRS (Krugman) Output Specialisation Indices for British Cities, (82 sectors), 1971, 1991 and 2014

(Cities ranked in descending order of specialisation for 1971)

\begin{tabular}{|c|c|c|c|c|c|c|c|}
\hline & 1971 & 1991 & 2014 & & 1971 & 1991 & 2014 \\
\hline Oxford & 0.723 & 0.420 & 0.375 & Stoke-on-Trent & 0.488 & 0.466 & 0.432 \\
\hline Kettering \& Wellingborough & 0.709 & 0.498 & 0.513 & Leicester & 0.488 & 0.348 & 0.368 \\
\hline Blackpool & 0.668 & 0.488 & 0.516 & Dundee & 0.488 & 0.471 & 0.432 \\
\hline Wolverhampton & 0.659 & 0.450 & 0.402 & Stevenage & 0.487 & 0.418 & 0.398 \\
\hline Basingstoke & 0.644 & 0.433 & 0.477 & Sheffield & 0.484 & 0.345 & 0.403 \\
\hline Swansea & 0.634 & 0.454 & 0.511 & Bournemouth & 0.484 & 0.365 & 0.313 \\
\hline Leamington Spa & 0.634 & 0.420 & 0.539 & High Wycombe \& Aylesbury & 0.481 & 0.330 & 0.399 \\
\hline Plymouth & 0.633 & 0.509 & 0.500 & Chelmsford & 0.481 & 0.334 & 0.279 \\
\hline Blackburn & 0.633 & 0.508 & 0.485 & Exeter & 0.480 & 0.397 & 0.408 \\
\hline Trowbridge & 0.600 & 0.451 & 0.281 & Tunbridge Wells & 0.479 & 0.380 & 0.332 \\
\hline Birkenhead & 0.593 & 0.552 & 0.400 & Bedford & 0.479 & 0.384 & 0.341 \\
\hline Chester & 0.590 & 0.416 & 0.399 & Cambridge & 0.479 & 0.405 & 0.365 \\
\hline Crewe & 0.590 & 0.439 & 0.412 & Peterborough & 0.478 & 0.360 & 0.323 \\
\hline Halifax & 0.582 & 0.443 & 0.432 & Telford & 0.478 & 0.507 & 0.511 \\
\hline Merthyr Tydfil & 0.580 & 0.491 & 0.547 & Hull & 0.477 & 0.418 & 0.500 \\
\hline Middlesbrough & 0.576 & 0.517 & 0.489 & Blyth \& Ashington & 0.476 & 0.472 & 0.541 \\
\hline Portsmouth & 0.567 & 0.427 & 0.372 & Shrewsbury & 0.472 & 0.405 & 0.424 \\
\hline Coventry & 0.559 & 0.527 & 0.432 & London & 0.468 & 0.548 & 0.643 \\
\hline Sunderland & 0.558 & 0.447 & 0.525 & Dunfermline \& Kirkcaldy & 0.467 & 0.439 & 0.436 \\
\hline Derby & 0.554 & 0.503 & 0.535 & Doncaster & 0.465 & 0.483 & 0.538 \\
\hline Medway & 0.551 & 0.361 & 0.297 & York & 0.463 & 0.532 & 0.419 \\
\hline Mansfield & 0.551 & 0.515 & 0.483 & Worcester \& Kidderminster & 0.457 & 0.483 & 0.361 \\
\hline Chesterfield & 0.551 & 0.505 & 0.444 & Guildford & 0.456 & 0.443 & 0.358 \\
\hline Reading & 0.546 & 0.446 & 0.587 & Eastbourne & 0.453 & 0.494 & 0.366 \\
\hline Dudley & 0.544 & 0.463 & 0.454 & Brighton & 0.446 & 0.372 & 0.333 \\
\hline Huddersfield & 0.542 & 0.459 & 0.450 & Ipswich & 0.438 & 0.432 & 0.309 \\
\hline Aberdeen & 0.542 & 1.044 & 0.744 & Crawley & 0.437 & 0.490 & 0.342 \\
\hline Barnsley & 0.535 & 0.488 & 0.487 & Norwich & 0.432 & 0.343 & 0.292 \\
\hline Milton Keynes & 0.532 & 0.359 & 0.423 & Birmingham & 0.427 & 0.374 & 0.275 \\
\hline Preston & 0.529 & 0.502 & 0.377 & Swindon & 0.426 & 0.316 & 0.435 \\
\hline Gloucester & 0.522 & 0.349 & 0.385 & Lincoln & 0.418 & 0.443 & 0.487 \\
\hline Bristol & 0.518 & 0.363 & 0.255 & Nottingham & 0.414 & 0.329 & 0.409 \\
\hline Wakefield & 0.515 & 0.486 & 0.479 & Southampton & 0.413 & 0.350 & 0.314 \\
\hline Newport & 0.508 & 0.455 & 0.492 & Southend & 0.386 & 0.397 & 0.331 \\
\hline Liverpool & 0.507 & 0.328 & 0.328 & Newcastle & 0.384 & 0.302 & 0.393 \\
\hline Falkirk and \& Stirling & 0.507 & 0.456 & 0.430 & Edinburgh & 0.381 & 0.389 & 0.430 \\
\hline Colchester & 0.504 & 0.426 & 0.358 & Leeds & 0.381 & 0.288 & 0.236 \\
\hline Motherwell \& Airdrie & 0.501 & 0.443 & 0.475 & Luton & 0.371 & 0.386 & 0.331 \\
\hline Bradford & 0.501 & 0.390 & 0.392 & Manchester & 0.353 & 0.332 & 0.200 \\
\hline Warrington \& Wigan & 0.498 & 0.388 & 0.401 & Cardiff & 0.339 & 0.330 & 0.373 \\
\hline Durham \&Bishop Auckland & 0.497 & 0.509 & 0.526 & Glasgow & 0.316 & 0.271 & 0.271 \\
\hline Northampton & 0.491 & 0.442 & 0.438 & Slough \& Heathrow & 0.294 & 0.397 & 0.489 \\
\hline Chichester & 0.489 & 0.419 & 0.340 & & & & \\
\hline
\end{tabular}

Note: London and major regional capitals ('Core cites') in bold

Table B.3: Hirschman-Herfindahl Employment Specialisation Indices for British Cities, (82 sectors), 1971, 1991 and 2014 (Cities ranked in descending order of specialisation for 1971

$\begin{array}{lrrrlrrrr} & \mathbf{1 9 7 1} & \mathbf{1 9 9 1} & \mathbf{2 0 1 4} & \mathbf{1 9 7 1} & \mathbf{1 9 9 1} & \mathbf{2 0 1 4} \\ \text { Oxford } & 0.081 & 0.052 & 0.054 & \text { York } & 0.046 & 0.045 & 0.045 \\ \text { Sunderland } & 0.077 & 0.043 & 0.045 & \text { Edinburgh } & \mathbf{0 . 0 4 5} & \mathbf{0 . 0 4 3} & \mathbf{0 . 0 4 3}\end{array}$




\begin{tabular}{|c|c|c|c|c|c|c|c|}
\hline Huddersfield & 0.072 & 0.041 & 0.046 & Peterborough & 0.045 & 0.039 & 0.045 \\
\hline Stoke-on-Trent & 0.071 & 0.050 & 0.044 & Aberdeen & 0.045 & 0.041 & 0.042 \\
\hline Halifax & 0.071 & 0.037 & 0.045 & Newport & 0.045 & 0.042 & 0.048 \\
\hline Dudley & 0.067 & 0.043 & 0.045 & Luton & 0.044 & 0.043 & 0.044 \\
\hline Trowbridge & 0.066 & 0.050 & 0.041 & Cambridge & 0.044 & 0.044 & 0.044 \\
\hline Bradford & 0.060 & 0.045 & 0.045 & Chesterfield & 0.043 & 0.047 & 0.042 \\
\hline Middlesbrough & 0.060 & 0.045 & 0.050 & Worcester \& Kidderminster & 0.043 & 0.048 & 0.043 \\
\hline Reading & 0.060 & 0.043 & 0.048 & Chichester & 0.043 & 0.046 & 0.044 \\
\hline Exeter & 0.059 & 0.044 & 0.047 & Leamington Spa & 0.043 & 0.039 & 0.036 \\
\hline Plymouth & 0.059 & 0.056 & 0.051 & Motherwell \& Airdrie & 0.043 & 0.045 & 0.044 \\
\hline Mansfield & 0.059 & 0.042 & 0.042 & Preston & 0.043 & 0.041 & 0.046 \\
\hline Gloucester & 0.059 & 0.039 & 0.043 & Nottingham & 0.043 & 0.042 & 0.050 \\
\hline Kettering \& Wellingborough & 0.059 & 0.039 & 0.041 & Lincoln & 0.042 & 0.038 & 0.043 \\
\hline Basingstoke & 0.058 & 0.040 & 0.041 & Bedford & 0.042 & 0.042 & 0.046 \\
\hline Swansea & 0.056 & 0.047 & 0.052 & Birmingham & 0.042 & 0.037 & 0.042 \\
\hline Wolverhampton & 0.056 & 0.039 & 0.043 & Crewe & 0.042 & 0.040 & 0.036 \\
\hline Portsmouth & 0.056 & 0.044 & 0.049 & Durham \& Bishop Auckland & 0.042 & 0.041 & 0.048 \\
\hline Falkirk and Stirling & 0.055 & 0.048 & 0.047 & Wakefield & 0.041 & 0.046 & 0.045 \\
\hline Colchester & 0.054 & 0.054 & 0.052 & Liverpool & 0.041 & 0.047 & 0.048 \\
\hline Dunfermline \& Kirkcaldy & 0.054 & 0.043 & 0.046 & Chester & 0.041 & 0.041 & 0.038 \\
\hline Medway & 0.053 & 0.041 & 0.044 & Tunbridge Wells & 0.041 & 0.043 & 0.041 \\
\hline Dundee & 0.053 & 0.047 & 0.054 & Norwich & 0.041 & 0.040 & 0.044 \\
\hline Blackburn & 0.052 & 0.039 & 0.044 & Brighton & 0.040 & 0.044 & 0.049 \\
\hline Coventry & 0.051 & 0.042 & 0.043 & Newcastle & 0.040 & 0.043 & 0.049 \\
\hline Chelmsford & 0.050 & 0.045 & 0.041 & High Wycombe \& Aylesbury & 0.040 & 0.039 & 0.044 \\
\hline Sheffield & 0.050 & 0.042 & 0.048 & Guildford & 0.039 & 0.040 & 0.041 \\
\hline Eastbourne & 0.049 & 0.058 & 0.050 & Cardiff & 0.039 & 0.040 & 0.047 \\
\hline Birkenhead & 0.049 & 0.050 & 0.050 & Hull & 0.039 & 0.046 & 0.043 \\
\hline Stevenage & 0.049 & 0.046 & 0.047 & Glasgow & 0.039 & 0.042 & 0.044 \\
\hline Blyth \& Ashington & 0.048 & 0.045 & 0.047 & Leicester & 0.038 & 0.037 & 0.040 \\
\hline Swindon & 0.048 & 0.039 & 0.037 & Milton Keynes & 0.038 & 0.041 & 0.041 \\
\hline Bristol & 0.047 & 0.040 & 0.042 & Shrewsbury & 0.038 & 0.042 & 0.045 \\
\hline Ipswich & 0.047 & 0.046 & 0.041 & Southampton & 0.038 & 0.042 & 0.045 \\
\hline Barnsley & 0.047 & 0.047 & 0.045 & Warrington \& Wigan & 0.038 & 0.039 & 0.039 \\
\hline Bournemouth & 0.047 & 0.043 & 0.045 & Leeds & 0.038 & 0.039 & 0.039 \\
\hline Northampton & 0.046 & 0.039 & 0.038 & Manchester & 0.037 & 0.040 & 0.039 \\
\hline Doncaster & 0.046 & 0.049 & 0.051 & London & 0.037 & 0.038 & 0.039 \\
\hline Telford & 0.046 & 0.045 & 0.042 & Blackpool & 0.037 & 0.047 & 0.045 \\
\hline Derby & 0.046 & 0.041 & 0.041 & Slough \& Heathrow & 0.035 & 0.036 & 0.037 \\
\hline Merthyr Tydfil & 0.046 & 0.038 & 0.049 & Crawley & 0.034 & 0.034 & 0.038 \\
\hline Southend & 0.046 & 0.047 & 0.047 & & & & \\
\hline
\end{tabular}

Note: London and major regional capitals ('Core cities') in bold

Table B.4: Hirschman-Herfindahl Output Specialisation Indices for British Cities, (82 sectors), 1971, 1991 and 2014 (Cities ranked in descending order of specialisation for 1971)

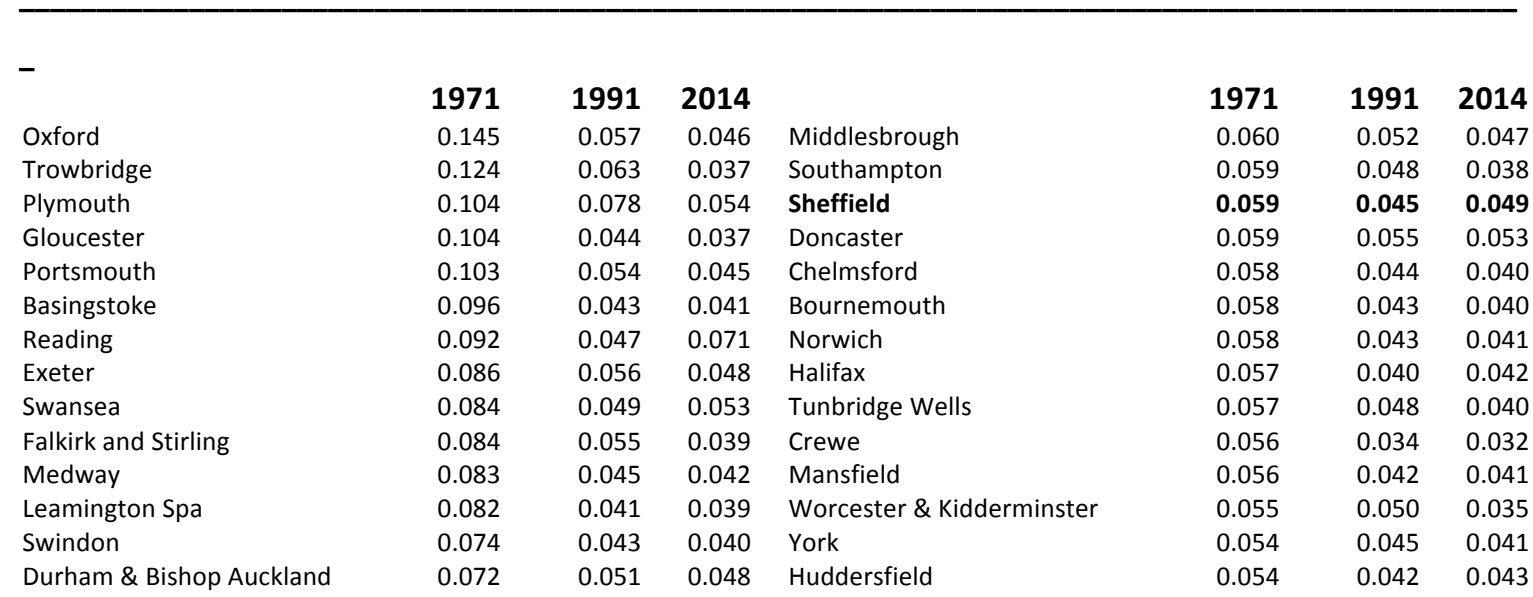




\begin{tabular}{|c|c|c|c|c|c|c|c|}
\hline Colchester & 0.072 & 0.052 & 0.046 & Brighton & 0.054 & 0.048 & 0.044 \\
\hline Kettering \& Wellingborough & 0.070 & 0.042 & 0.042 & Bradford & 0.053 & 0.042 & 0.042 \\
\hline Dundee & 0.069 & 0.054 & 0.045 & Motherwell \& Airdrie & 0.053 & 0.049 & 0.040 \\
\hline Dunfermline \& Kirkcaldy & 0.069 & 0.045 & 0.040 & Derby & 0.052 & 0.044 & 0.047 \\
\hline Eastbourne & 0.069 & 0.057 & 0.045 & Birkenhead & 0.052 & 0.047 & 0.038 \\
\hline Wolverhampton & 0.066 & 0.044 & 0.040 & Chester & 0.052 & 0.038 & 0.032 \\
\hline Telford & 0.066 & 0.050 & 0.040 & Milton Keynes & 0.052 & 0.040 & 0.044 \\
\hline Dudley & 0.065 & 0.045 & 0.042 & Glasgow & 0.051 & 0.049 & 0.038 \\
\hline Stoke-on-Trent & 0.064 & 0.048 & 0.040 & Wakefield & 0.051 & 0.047 & 0.044 \\
\hline Coventry & 0.064 & 0.054 & 0.039 & Birmingham & 0.051 & 0.041 & 0.039 \\
\hline High Wycombe \& Aylesbury & 0.064 & 0.040 & 0.045 & Stevenage & 0.050 & 0.040 & 0.042 \\
\hline Aberdeen & 0.063 & 0.144 & 0.060 & Bedford & 0.050 & 0.043 & 0.044 \\
\hline Lincoln & 0.063 & 0.044 & 0.047 & Shrewsbury & 0.050 & 0.046 & 0.042 \\
\hline Blyth and Ashington & 0.062 & 0.050 & 0.044 & Warrington \& Wigan & 0.047 & 0.036 & 0.034 \\
\hline Peterborough & 0.061 & 0.039 & 0.039 & Crawley & 0.047 & 0.035 & 0.035 \\
\hline Northampton & 0.061 & 0.043 & 0.040 & Leeds & 0.046 & 0.038 & 0.038 \\
\hline Merthyr Tydfil & 0.061 & 0.043 & 0.047 & Leicester & 0.046 & 0.040 & 0.038 \\
\hline Barnsley & 0.061 & 0.053 & 0.046 & Liverpool & 0.045 & 0.041 & 0.039 \\
\hline Ipswich & 0.061 & 0.053 & 0.038 & Nottingham & 0.045 & 0.040 & 0.046 \\
\hline Chesterfield & 0.061 & 0.051 & 0.043 & Manchester & 0.044 & 0.043 & 0.035 \\
\hline Newcastle & 0.061 & 0.046 & 0.049 & Blackburn & 0.043 & 0.037 & 0.038 \\
\hline Cambridge & 0.060 & 0.044 & 0.039 & Hull & 0.043 & 0.045 & 0.039 \\
\hline Newport & 0.060 & 0.043 & 0.046 & Blackpool & 0.039 & 0.045 & 0.043 \\
\hline Guildford & 0.060 & 0.042 & 0.041 & & & & \\
\hline
\end{tabular}

Note: London and major regional capitals ('Core cities') in bold

\section{References}

Acemoglu, D.and Autor, D. (2011) Skills, Tasks and Technologies: Implications r Employment and Earnings, Ch 12 in Ashenfelter, O. and Card, D. (eds) Handbook of Labour Economics, Vol 4b, North Holland, pp. 1044-1171

Aiginger, K. and Davies, S. (2004) Industrial specialization and geographic concentration: two sides of the same coin? Not for the European Union, Journal of Applied Economics, 12, pp. 231-248.

Aiginger, K. and M. Pfaffermayr (2004) The Single Market and geographic concentration in Europe, Review of International Economics, 12, pp. 1-11.

Altunbas, Y., Jones, E. and Thornton, J. (2012) Knowledge spillovers and the growth of cities, Applied Economics Letters, 20, pp. 162-166.

Andrews, D., Criscuolo, C. and Gal, P. (2015) Frontier firms, technology diffusion and public policy: Micro evidence from OECD countries, Paris: OECD

Ansari, M. R., Mussida, C. and Pastore, F. (2013) Note on the Lilien and Modifed Lilien Index, Discussion Paper 7198, Institute for the Study of Labour, Bonn, Germany.

Arrow, K. (1962) The Economic Implications of Learning by Doing, Review of Economic Studies, 29 (3), pp. 155-73. 
Bahl, R.W., Firestine, R. and Phares, D. (1971), Industrial diversity in urban areas: alternative measures and intermetropolitan comparisons, Economic Geography,

47, pp. 414-425.

Baily, M.N., Hulten, C. and Campbell, D. (1992) Productivity dynamics in manufacturing plants, Brookings Papers on Economic Activity, Microeconomics, pp. 187-267.

Baily, M.N., Bartelsman, E.J. and Haltiwanger, J.C. (2001) Labor productivity: structural change and cyclical dynamics, Review of Economics and Statistics 83, pp. 420-433.

Baily, M.N. and Solow R.M. (2001) International productivity comparisons built from the firm level, The Journal of Economic Perspectives 15, 3, 151-172.

Baldwin, R. (2016) The Great Convergence: Information Technology and the New Globalisation, Cambridge, Mass: Belknap Press.

Baldwin, R., Forslid, R., Martin, P., Ottaviano, G. and Robert-Nicoud, F. (2002) Economic Geography and Public Policy, Princeton, Princeton University Press.

Baldwin, R. and Everitt, S. (2014) Value Creation and Trade in 21 ${ }^{\text {st }}$ Century Manufacturing: What Policies for UK Manufacturing? Ch. 4 in Greenaway, D. (Ed) The UK in a Global World, Department of Business, Innovation and Skills, London, pp. 71-128.

Bartelsman, E. and Doms, M. (2000) Understanding productivity: Lessons from longitudinal microdata, Journal of Economic Literature, 38, 3, pp. 569-594.

Baumol, W.J. (1967) Macroeconomics of unbalanced growth: the anatomy of urban crisis, American Economic Review 57, pp. 415-426.

Baumol, W.J., Blackman, S.A.B. and Wolff, E.N. (1985) Unbalanced growth revisited: asymptotic stagnancy and new evidence, American Economic Review 75, pp. 806-817.

Beaudry, C. and Schiffauerova, A. (2009) Who's right, Marshall or Jacobs? The localization versus urbanisation debate, Research policy, 38, pp. 318-337.

Beine, M. and S. Coulombe (2007), Economic integration and the diversification of regional exports: evidence from the Canadian-U.S. Free Trade Agreement, Journal of Economic Geography, vol. 7, pp. 93-111.

Boschma, R. (2016) Relatedness as a driver of regional diversification: a research agenda, Regional Studies DOI: 10.1080/00343404.2016.1254767

Brakman, S., Garretsen J.H. and Marrewijk, C. (2009) The New Introduction to Geographical Economics, Cambridge: Cambridge Universitfy Press. 
Brülhart, M. and Traeger, R. (2005), An account of geographic concentration patterns in Europe, Regional Science and Urban Economics, 35, pp. 597-624.

Cantner, U. and Krüger, J.J. (2006) Micro-heterogeneity and aggregate productivity development in the German manufacturing sector: results from a decomposition exercise, Discussion Paper 02/2006 Jenaer Schriften zur Wirtschaftswissenschaft, , Friedrich-Schiller-University Jena.

Carmody, C. (2013) Slowing Productivity Growth: A Developed Economy Comparison, Economic Roundup, Issue 2, The Treasury, Australian Government, http://www.treasury.gov.au/PublicationsAndMedia/Publications/2013/Econ omic-Roundup-Issue-2/Economic-Roundup/Slowing-productivity-growth

Chisholm, M. and J. Oeppen (1973) The Changing Pattern of Employment. Regional Specialisation and Industrial Location in Britain, Beckenham: Croom Helm

Conway, P. and Nicoletti, G. (2007) Product Market Regulation and Productivity Convergence: OECD evidence and implications for Canada, International Productivity Monitor, 15, pp 3-24

Cornwall, J. and Cornwall, W. (1994) Growth theory and economic structure, Economica, NS 61, 242, pp. 237-251.

Cowell, M. (2014) Deindustrialisation: Adaptive Resilience in American Midwestern Regions, London: Routledge.

Cowen, T. (2016) Silicon Valley has not saved us from a productivity slowdown, Economic Review, The New York Times, 4 March

(http://www.nytimes.com/2016/03/06/upshot/silicon-valley-has-not-savedus-from-a-productivity-slowdown.html)

Coyle, D. (2014) GDP: A Brief but Affectionate History, Oxford: Princeton University Press.

Crafts, N. (2002) The Solow Productivity Paradox in historical perspective, Discussion Paper 3142, Centre for Economic Policy Research, London School of Economics.

Cuadrado-Roura, J.R., Garcia-Greciano, B. and. Raymond, J.L. (1999) Regional convergence in productivity and productive structure: The Spanish case, International Regional Science Review, 22, 35-53.

Davis, D.R. (1998) The Home Market, Trade, and Industrial Structure, American Economic Review, vol. 88, 1264-1276.

Department of Business, Energy and Industrial Strategy (2017) Industrial Strategy: Building a Britain fit for the Future, Department of Business, Energy and Industrial Strategy, London. 
Dijkstra, L., Garcilazo, E. and McCann, P. (2013) The economic performance of European cities and city-regions: myths and realities, European Planning Studies, 21, pp. 334-354.

Disney, R., Haskel, J. and Heden, Y. (2003), Restructuring and productivity growth in UK Manufacturing, Economic Journal, 103, pp. 666-694.

Dixon, R J. and Thirlwall, A.P. (1975) Regional Growth and Unemployment in the United Kingdom, London: Macmillan Press.

Dolman, B. (2009) What Happened to Australia's Productivity Surge? Australian Economic Review, 42, pp. 243-263.

Dupont, J., Guellec, D. and Martins, J. (2011) OECD Productivity Growth in the 2000s: A Descriptive Analysis of the Impact of Sectoral Effects and Innovation, OECD Journal of Economic Studies, 44, pp. 1-23

Duranton, G. (2007) Urban evolutions: The fast, the slow and the still, American Economic Review, 97, 1, pp. 197-221.

Duranton, G. and Puga, D. (1999) Diversity and Specialisation in Cities: Why, Where and When Does it Matter? Research Papers in Environmental and Spatial Analysis 56, Department of Geography and Environment, London School of Economics.

European Central Bank (2016) The slowdown in US labour productivity growth - stylised facts and economic implications, ECB (https://www.ecb.europa.eu/pub/pdf/other/eb201602_focus01.en.pdf)

Ezcurra, R. and P. Pascual (2007) Spatial Disparities in Productivity in Central and Eastern Europe, Eastern European Economics, 45, pp. 5-32.

Fagerberg, J. (2000) Technological progress, structural change and productivity growth: a comparative study, Structural Change and Economic Dynamics, 11, pp. 393-411.

Farhauer, 0. and Kröll, A. (2012) Diversified specialisation: Going one step beyond regional economics' specialisation-diversification concept, Jahrbuch für RegionalWissenschaft, 32, 1, pp. 63-84.

Feldman, M.P. and Audretsch, D. (1999) Innovation in cities: Science-based diversity, specialisation and localised competition, European Economic Review, 43, pp. 409-429.

Findeisen, S. And Südekum, J. (2008) Industry churning and the evolution of cities: Evidence for Germany, Journal of Urban Economics, 64, pp. 326-339.

Forida, R. (2008) Whose Your City? How the Creative Economy Is Making Where To Live the Most Important Decision of Your Life, New Yok: Random House 
Foster, L., Haltiwanger, J. and Krizan, C.J. (1998), Aggregate Productivity

Growth: Lessons from Microeconomic Evidence, NBER Working Paper 6803.

Freeman, C. and Louca, F. (2001) As Time Goes By: From the Industrial Revolutions to the Information Revolution, New York: Oxford University Press.

Frenken, K., Van Oort, F.G., and Verburg, T. (2007) Related variety, unrelated variety and regional growth, Regional Studies, 41, pp. 685-697.

Gibbs, J.P. and Postan, D.L. (1975) The division of labor: conceptualisation and related measures, Social Forces, 53, pp.

Glaeser E., Kallal H.D., Scheinkman J.A., and Shleifer, A. (1992) Growth of cities. Journal of Political Economy, 100, pp. 1126-1152.

Glaeser, E. (2005) Reinventing Boston: 1640-2003, Journal of Economic Geography, 5, pp. 119-153.

Glaeser, E. (2011) Triumph of the City, London: Macmillan.

Gordon, R. J. (2016) The Rise and Fall of American Growth, Princeton: Princeton University Press.

Griliches, Z. and Regev, H. (1995) Productivity and firm turnover in Israeli industry, 1979-1988, Journal of Econometrics, 65, pp. 175-203.

Haaland, J.I. Kind, H.J., Midelfart-Knarvik, K.H. and J. Torstensson (1999) What determines the economic geography of Europe? CEPR Discussion Paper, No. 2072, London School of Economics.

Haldane, A.G. (2017) Productivity Puzzles, Bank of England Speech, London School of Economics (www.bankofengland.co.uk/speeches)

Haltiwanger, J. (2000) Aggregate growth: What we have learned from microeconomic evidence, OECD Economics Department Working Papers No. 267, OECD, Paris

Harris, R. and Moffat, J. (2015) Total factor productivity growth in Local Enterprise Partnership Regions in Britain, 1997-2008, Regional Studies 49, 6, 1019-1041.

H.M. Treasury (2015) Fixing the Foundations: Creating a More Prosperous Nation, HM Treasury, Cm 9098, London.

Hobor, G. (2013) Surviving the era of deindustrialisation: the new economic geography of the urban rust belt, Journal of Urban Affairs, 35, pp. 417-443

Hottman, C., Redding, S. and Weinstein, D. (2016) Quantifying the sources of frim heterogeneity, The Quarterly Journal of Economics, pp. 1291-1364. 
Isard, W. and others (1960) Methods of Regional Analysis: An Introduction to Regional Science, Cambridge, Mass: MIT Press.

Jacobs, J. (1969) The Economy of Cities, New York: Random House.

Jacobs, J. (1984) Cities and the Wealth of Nations: Principles of Economic Life, New York: Random House

Kaldor, N. (1981) The role of increasing returns, technical progress and cumulative causation in the theory of international trade and economic growth, Economic Appliqué, 34, pp. 593-617.

Kemeny, T. and Storper, M. (2015) Is specialisation good for regional growth? Regional Studies 49, pp. 1003-1018.

Kim, H-J. (2006) The Shift to the Service Economy: Causes and Effects, Research Paper 2006.7.7, Institute for Monetary and Economic Research, The Bank of Korea.

(https://faculty.washington.edu/karyiu/confer/seoul06/papers/kim_hj.pdf)

Krüger, J. J. (2006) The Sources of Aggregate Productivity Growth: US Manufacturing Industries, 1958-1996, Discussion Paper 10/2006, Jenaer Schriften zur Wirtschaftswissenschaft, Friedich-Schiller University, Jena.

Krüger, J. J. (2008) Productivity and Structural Change: A Review of the Literature, Journal of Economic Surveys, 22, pp. 330-363.

Krugman, P. (1991) Increasing returns and economic geography, Journal of Political Economy 99, pp. 183-199.

Krugman, P. (1993) Lessons of Massachusetts for EMU, pp. 241-261 in Torres F. and Giavazzi, F. (eds) Adjustment and Growth in the European Monetary Union, Cambridge: Cambridge University Press.

Krugman, P. (1994) The Age of Diminished Expectations, Cambridge, Mass: MIT Press.

Kucera, D. and Roncaolato, L. (2012) Structure Matters: Sectoral Drivers of Growth and the Labour Productivity-Employment Relationship, ILO Research Paper 3, Geneva: International Labor Office

Kuznets, S. (1957) Quantitative aspects of the economic growth of nations: II. Industrial distribution of national product and labour force, Economic Development and Cultural Change, 5 (Supplement), pp. 3-111.

Kuznets, S. (1973) Modern economic growth: findings and reflections, American Economic Review, 63, pp.47-258.

Laitner, J. (2000) Structural change and economic growth, Review of Economic Studies, 67, pp. 545-561. 
Landesmann, M. (2000), Structural change in the Transition Economies 19891999, Economic Survey of Europe, 2, pp. 95-123.

Lilien, D.M. (1982) Sectoral Shifts and Cyclical Unemployment, Journal of Political Economy, 90, pp. 777-793.

Lindbeck, A. (1983) The recent slowdown of productivity growth, Economic Journal, 93, pp.

Markusen, A. and Shrock, (2006) The distinctive city: divergent patterns in growth, hierarchy and specialisation, Urban Studies, 43, pp. 1301-1323.

Martin, R.L. (1988) The political economy of Britain's North-South Divide, Transactions of the Institute of British Geographers, 13, pp. 389-418.

Martin, R.L. (2015) Spatially rebalancing the economy: The challenge for Regional Theory, Territory, Politics, Governance, 3, pp. 235-272.

Martin, R.L. (2016) Divergent urban development: reflections on a tale of two cities, Regional Studies, 50, pp. 1623-1627.

Martin, R.L. (2017) Cumulative causation, endogenous growth and regional development, in Richardson, D. (Ed) The International Encyclopedia of Geography: People, the Earth, Environment and Technology, New York: Wiley, pp. 1223-1235.

Martin, R. L., Gardiner, B. and Tyler, P. (2014) The Evolving Economic Performance of UK Cities: City Growth Patterns, 1981-2011, Foresight Future Cities Working Paper, UK Government Office for Science, London.

Martin, R.L., Sunley, P., Tyler, P. and Gardiner, B. (2016) Divergent cities in post-industrial Britain, Cambridge Journal of Regions, Economy and Society, 9, pp. 269-299.

Massey, D. (1984) Spatial Divisions of Labour, London: Macmillan.

McMillan, M.S. and Rodrik, D. (2011) Structural change and productivity growth, Working Paper 17143, National Bureau of Economic Research, Cambridge, Mass.

Melitz, M. (2003) The impact of trade on intra-industry reallocations and aggregate industry productivity, Econometrica, 71, pp 1695-1725.

Melitz, M. and Redding, S. (2012) Heterogeneous firms and trade, Centre for Economic Performance, LSE, Discussion Paper 1183.

Metcalfe, J.S., Foster, J. and Ramlogan, R. (2006) Adaptive economic growth, Cambridge Journal of Economics, 30, pp. 7-32. 
Michaels, G., Rauch, F. and Redding, S. (2013) Task specialisation in US cities, Working Paper 18715, National Bureau of Economic Research , Washington.

Moretti, E. (2013) The New Geography of Jobs, Boston: Mariner Books.

Muro, M. and Parilla, J. (2017) Why some US cities are so much more productive than others, Wall Street Journal, 18 May (https://blogs.wsj.com/experts/2017/05/18/why-some-u-s-cities-are-somuch-more-productive-than-others/)

Ocampo, J. A., Rada, C. and Taylor, L. (2009). Growth and Policy in Developing Countries: A Structuralist Approach. New York: Columbia University Press.

OECD (2015) The Future of Productivity, Paris: OECD.

Oguz, S. (2017) Regional firm-level productivity analysis for the non-financial business economy: January 2017, ONS London.

Olley, G.S. and Pakes, A. (1996) The dynamics of productivity in the telecommunications equipment industry, Econometrica, 64, pp. 1263-1297 Ottaviano, G. (2011) 'New' new economic geography: firm heterogenenity and agglomeration economies, Journal of Economic Geography 11, pp. 231-240.

Oulton, N. (2001) Must the growth rate decline? Baumol's unbalanced growth revisited, Oxford Economic Papers, 53, pp. 605-627.

Owen, T. (2011) The Great Stagnation: How America Ate All the Low-Hanging Fruit of Modern History, Got Sick, and Will (Eventually) Feel Better, New York: Dutton)

Palan, N. (2010) Measurement of Specialisation: The Choice of Indices, Working Paper 62, Forschungsschwerpunkt Internationale Wirtschaft, Vienna.

Pasinetti, L. (1981) Structural Change and Economics Dynamics, Cambridge: Cambridge University Press.

Pasinetti, L. (1993) Structural Economic Dynamics, Cambridge: Cambridge University Press.

Pieper, U. (2000) Deindustrialization and the social and economic sustainability nexus in developing countries: Cross-country evidence on productivity and employment, Journal of Development Studies, 36, pp. 66-99.

Peneder, M. (2003) Industrial structure and aggregate growth, Structural Change and Economic Dynamics 14, pp. 427-448.

Percoco, M., Dall'erba, S. and Hewings, G. (2005) Structural convergence of the national economies of Europe, MPRA Paper, No. 1380. 
Pilat, D. Lee, F. and van Ark, B. (2002) Production and Use of ICT: A Sectoral Perspective on Productivity Growth in the OECD Area, OECD Economic Studies, 35 , pp 47-78.

Potter, A. and Watts, H.D. (2011) Evolutionary agglomeration theory: increasing returns, decreasing returns and the industry life cycle, Journal of Economic Geography, 11, pp. 417-455.

Power, A., Plöger, J. and Winkler, A. (2010) The Fall and Rise of Great Industrial Cities, Bristol: The Polity Press.

Riley, R. and Bondibene, C. (2016) Sources of labour productivity growth at a sector level in Britain, after 2007, a firm level analysis, NESTA Working Paper $16 / 01$.

Romer, P. (1986) Increasing Returns and Long Run Growth, Journal of Political Economy, 94, pp. 1002-1037.

Roncolato, L. and Kucera, D. (2014) Structural Drivers of Productivity and Employment Growth: A Decomposition Analysis for 81 Countries, Cambridge Journal of Economics, 38, pp. 399-424.

Rosenthal. S. and Strange, W. (2003) Geography, industrial organization, and agglomeration, Review of Economics and Statistics, 85, 2, pp. 377-393.

Rowthorn, R.E. (2010) Combined and Uneven Development: Reflections on the North-South Divide, Spatial Economic Analysis, 5, pp. 363-388.

Sapir, A. (1996), The effects of Europe's internal market program on production and trade: A first assessment, Weltwirtschaftliches Archiv, 132, pp.457-475.

Scott, M.F. (1989) A New View of Economic Growth, Oxford: Clarenden Press.

Storper, M., Chen, Y. and De Paolis, F. (2002), Trade and the location of industries in the OECD and European Union, Journal of Economic Geography, vol. 2, pp. 73-107.

Storper, M. (2013) Keys to the City: How Economics, Institutions, Social Interaction, and Politics Shape Development, Princeton: Princeton University Press.

Storper, M., Kemeny, T., Makarem, N.P. and Osman, T. (2015) The Rise and Fall of Cities: Lessons from San Francisco and Los Angeles, Stanford: Stanford University Press.

Syverson, C. (2016) Challenges to mismeasurement explanations for the US productivity slowdown, Working Paper 21974, National Bureau of Economic Research, Cambridge Mass. 
Timmer, M. P., and de Vries, G. J. (2009) Structural change and growth accelerations in Asia and Latin America: a new sectoral data set, Cliometrica, 3, pp. 165-190.

Triplett, J.E. (1999) The Solow Productivity Paradox: what do computers do to productivity, Canadian Journal of Economics, 32, pp. 309-334.

Van der Panne, G. (2004) Agglomeration externalities: Marshall versus Jacobs, Journal of Evolutionary Economics, 14, pp. 593-604.

Webber, D.J., Hudson, J., Boddy, M. and Plumridge, A. (2009) Regional productivity differentials in England: explaining the gap, Papers in Regional Science, 88, pp. 609-621.

Williamson, J.G. (1991) Productivity and American leadership: a review article. Journal of Economic Literature 29, pp. 51-68.

World Bank (2008) Unleashing Prosperity, Washington: World Bank. (http://siteresources.worldbank.org/ECAEXT/Resources/publications/Unleas hingProsperity_2.pdf) 